\title{
Which Regions Matter for MNEs? The Role of Regional and Firm Level Differences
}

\author{
Mehmet Demirbag* \\ Essex Business School, University of Essex, Southend-on-Sea, SSO ODH United Kingdom \\ Email: mdemirc@essex.ac.uk; Tel: +44 (0)1702 324670
}

Keith W. Glaister

Leeds University Business School, University of Leeds, LS2 9JT, United Kingdom

Email: k.w.glaister@leeds.ac.uk; Tel: +44 (0)113 3431909

\author{
Abhijit Sengupta \\ Kent Business School, University of Kent, Canterbury CT2 7PE United Kingdom \\ Email: asengua@essex.ac.uk; Tel: +44 (0)1227816595
}

\begin{abstract}
*Corresponding author:
Professor Mehmet Demirbag

Essex Business School

University of Essex

Southend-on-Sea, SS0 0DH

United Kingdom

Email: mdemirc@essex.ac.uk;

Tel: +44 (0)1702 324670
\end{abstract}




\title{
Which Regions Matter for MNEs? The Role of Regional and Firm Level Differences
}

\begin{abstract}
This paper explores the impact of regional and firm level heterogeneity on MNE performance from an operational perspective. We find that the underlying economic growth of a region and the MNE's overall product diversity significantly impact returns from downstream operations in specific regions. Based on a 10 year panel dataset of 1249 US based MNEs, results show that the incremental impact of the degree and speed of operations within a given region, is greater for regions exhibiting faster economic growth than for slower growing ones. For slower growing regions only, product diversity of the MNE becomes important and negatively moderates the link between operations and performance. Previous literature has shown that MNEs largely follow a regional strategy and has ignored the role of inter-regional differences, and how firm level characteristics interact with region specific ones. Once inter-regional heterogeneity is introduced, a more complex picture of the internationalization performance link emerges than has been addressed previously, with significant implications for the theory and practise of internationalization.
\end{abstract}

Keywords: Regional Strategy, Degree of regional operations, Speed of operations, Product Diversity, MNE Performance. 


\section{Introduction}

Research on internationalization has increasingly focussed on the regional character of multinational enterprises (MNEs). The seminal work of Rugman and Verbeke (2004) and Rugman (2005), followed by more recent studies (Arregle et al., 2013; Qian et al., 2008; Verbeke and Asmussen, 2016) emphasize the regional nature of MNEs in terms of international sales and operations, and their home region bias. A parallel strand of literature has emphasized the structural aspects of globally disaggregated MNEs and has studied regional management strategies, particularly through the presence of regional headquarters (Chakravarty et al., 2017; Lasserre, 1996; Schotter et al., 2017). However, the regional focus of MNEs (often termed as "regionalization") and its impact on performance is relatively under researched and not well understood. This paper attempts to unravel this relationship by examining how inter-regional and inter-firm differences translate into differences in the returns from MNEs' downstream operations across several regions simultaneously. Through a novel study of the impact of regional operations on firm level outcomes, we contribute to the broader internationalization - performance debate in a nuanced and novel manner, which has important consequences for both theory and practise of international business.

A "region" has been conceptualised as a grouping of geographically proximate nations (Arregle et al., 2013; Rugman and Verbeke, 2004). Although the regional dimension has been increasingly examined (Verbeke and Asmussen, 2016), studies of how various supra-national regions and their underlying differences affect the MNE's returns from operations is limited. Further, there has been little exploration of whether the impact of these regional differences is magnified or dampened by firm level strategic differences. This gap has been accentuated as prior research has largely considered the locus of internationalization to be either specific host countries (Nguyen, 2017; Yang et al., 2013) or a homogenous geography outside the home country or region (Asmussen, 2009; Oh and Contractor, 2014). This also applies to research that has explored the regional dimension strategically, for example, Arregle et al. (2013), where the focus of internationalization from the firm's perspective is the country and not the region.

Inter-regional differences can and do have a significant impact on a MNE's strategy. It is well established that MNEs explicitly recognize and incorporate regional divisions within their strategic outlook as well as within their organizational design, although the definitions of regions and regional boundaries may vary among firms (Verbeke et al., 2016). Yet the literature is unclear on the impact that regional strategy has on performance, compared with having a more homogenous global strategy. In this paper we argue that the impact on performance is driven by inter-regional differences., These differences result in a complex multi-dimensional mapping in which operations within each region leaves its unique signature on overall performance. This perspective differs from the extant internationalization - performance literature, where the mapping between the two is assumed to be 
unique. Since inter-regional differences pose constraints on the transferability, deployment and exploitation of assets across regions (Ghemawat, 2001), it is in the interest of MNEs to be aware of how these differences translate into differences in performance from operations across regions. This knowledge is critical, as it allows MNEs to prioritise optimally between regions and to allocate resources centrally across them. Also, from a theoretical perspective, a possible resolution of the largely inconclusive internationalization - performance literature becomes possible once interregional differences are considered. However, as previously noted, very little research has actually been undertaken to explore the role of these inter-regional differences on MNE performance and strategy.

These limitations lead us to address the following research questions: (1) When MNES can operate across multiple supra-national regions, how do operations in specific regions affect their performance,? (2) Are the regional operations - performance relationships affected by underlying characteristics of the regions themselves? (3) Are the regional operations - performance relationships affected by strategic characteristics of the MNE?

We focus on the region's underlying economic growth in question (2) and the firm's overall product diversity as the relevant MNE characteristic in question (3). For all three research questions, we consider two operational characteristics per region, the sales within the region as a proportion of overall global sales of an MNE (henceforth referred to as the degree of operations for this region), and the rate at which the degree of operations has changed over time (henceforth referred to as the speed of operations for this region).

Prior literature has examined regionalization strategy in terms of operations within the home region versus anywhere outside it (Qian et al., 2010), through the lens of firm specific advantages (FSAs), such as size, experience and technology (Erramilli et al., 1997). The geographic space outside the home region has generally been considered as a homogeneous unit. However, host regions themselves may differ amongst each other economically, institutionally and culturally. For instance, from an economic perspective, the four major global regions - Asia Pacific, Americas, Europe, Africa - have witnessed very different aggregate GDP and aggregate GDP per capita growth rates, in comparison to each other ${ }^{1}$. Such economic differences, coupled with key institutional and cultural differences, point towards significant differences in the contexts within which MNEs would operate within each of these regions (Arregle et al.et al., 2013). The transaction cost argument implies that as firms start to deploy resources within a host region, asset specificity leads MNEs to upgrade their FSAs specifically to take advantage of cross border asset mobilization and utilization within the region rather than across it (Arregle et al., 2013; Sapienza et al., 2006; Teece, 1982). Hence, if regions are fundamentally

1 IMF Regional Economic Outlook, 2016. Details on growth rates are provided in Table 4 presented later. 
different from each other, the question of whether specific regions are strategically advantageous (or problematic) for expansion, becomes pertinent.

We find that while multinational firms are indeed regional players, some specific host regions can be strategically more important than others, where the impact of incremental degree or speed of operations is related to better performance. These high-performance regions coincide with regions exhibiting high rates of economic growth. Furthermore, in those regions where the returns are relatively lower than others, that is, those which can be considered to be relatively more "difficult" to operate in, the MNE's product diversity becomes critical. Thus, our research contributes to the regionalization literature by introducing the simultaneous impact of regions explicitly into the analysis and is able to shed new light onto the widely discussed internationalization-performance puzzle within international business (Nguyen, 2017; Ral-Trebacz and Eckert, 2016).

In the next section, we discuss both these strands of literature to build the theoretical framework on which this study is based.

\section{Literature Review and Hypotheses Development}

The regional view of MNEs is well established within the international business literature, and it is now accepted that MNEs largely adopt a regional strategy as opposed to a global one (Rugman et al., 2011; Verbeke and Kano, 2016). However, the literature remains unclear about the impact of regional operations on the overall performance of an MNE, and in particular, how regional and firm level characteristics affect this relationship (Verbeke et al., 2016). This is especially relevant given the increased focus on the "geography" of FDI in recent literature (Qian, Li and Rugman, 2013; Yang et al., 2013) and as firms continue to diversify geographically in both upstream and downstream operations (Verbeke and Asmussen, 2016). Specifically, firms need to be aware geographically of where the maximum returns from investment lie and what strategies are useful in overcoming the liability of foreignness in the relatively difficult regions.

Several scholars have explored the regional dimension and its impact on performance, notable among them Qian et al. $(2008,2013)$ and more recently, Ral-Trebacz and Eckert (2016), however, there is a clear point of departure in the focus of this study. Whereas different regions are treated homogenously in prior research, we explore the impact of operations across multiple regions explicitly and simultaneously. Others have explored the differential impact of intra-regional versus inter-regional strategy on firm performance (Qian et al., 2010; Ruigrok et al., 2013; Sukpanich and Rugman, 2007), but findings have been contradictory. Regionalization is an important instrument within a MNE's internationalization strategy, but without a clear understanding of how operations across multiple regions affect performance, and factors which impact these relationships, researchers and practitioners will not be able to utilize this key instrument effectively. 


\section{International Operations, Regionalization and Performance}

Benefits accruing to a MNE from international operations are primarily in the form of economies of scale and scope, and exploitation of national differences (Rugman and Verbeke, 1992). Based on the resource-based view of the firm (Rugman, 1981), "non-location bound" FSAs are key to success for an international firm. In practise, this is achieved through a recombination of internal and home country resources with resources located in foreign locations (Rugman and Verbeke, 2005; Verbeke et al., 2012). Costs are often attributed to geographic, cultural and legal distances (Ghemawat, 2001) between home and host regions or countries. Regions more distant in terms of any of these dimensions entail higher transaction costs (Verbeke and Asmussen, 2016), complexity of operations (Williamson, 1985) and the liability of foreignness (Zaheer and Mosakowski, 1997). Risk and uncertainty associated with unfamiliar environments also play a part in reducing performance as the firm expands into foreign regions (Oh and Contractor, 2012), as do coordination problems between various learning strategies adopted at the organisational level regarding offshore opportunities (Asmussen et al., 2016).

Given the theoretical and practical complexities associated with the effects of international operations, it is not surprising that empirical studies do not reveal a consistent set of findings on the impact of internationalisation on performance. Some have found a tension between international operations and performance in the form of a negative trade-off (Delios and Beamish, 2005; Elango, 2004), while others established a positive relationship (Tallman and Li, 1996). Non-linearity has been widely explored, most notably in Contractor et al. (2003) and Lu and Beamish (2004), and subsequently in Oh and Contractor (2014), in the form of S-shaped relationships. Several studies have also found U or inverted U-shaped relationships incorporating both positive and negative performance (Gomes and Ramaswamy, 1999; Hitt et al., 1997), others have found an inverted J-shaped relationship (Daniels and Bracker, 1989; Li, 2007).

In some of the above cases, the contradictory findings may be attributable to methodological issues, such as, endogeneity and measurement errors (Hennart, 2011; Verbeke and Asmussen, 2016), nevertheless, the "regional" perspective has an important role to play in resolving the discrepancies from both theoretical and empirical perspectives (Nguyen, 2017; Ral-Trebacz and Eckert, 2016). The region provides a balance between the context specificity of host countries, versus the more general view of internationalization as a homogenous activity outside the home country or region, and this becomes relevant for two important reasons.

First, countries within a region are expected to exhibit a greater degree of homogeneity among themselves than they are with countries in other regions - thus reducing the so called discontinuous "spike" in the distance metric at the intra-region boundaries (Beugelsdijk and Mudambi, 2013; Rugman et al., 2011; Verbeke and Asmussen, 2016). The spike occurs primarily due to differences or 
barriers in geography, culture, institutional and economic elements between two regions, which compound and feed back on each other for firms operating in one region but attempting to enter another (Verbeke et al., 2016). To overcome this spike in compounded distance, firms are required to adopt specific strategies to either upgrade their existing home region bound FSAs to be more appropriate for the host region (Rugman et al., 2010) or to fine tune their already non-location bound FSAs as a region-specific responsive strategy (Verbeke and Asmussen, 2016).

Second, examining international operations at the country level is unduly restrictive as it ignores the potential for greater economies of scale and scope and for cross border synergies that may exist within a region. Previous studies have pointed towards linkages between globalization and regional development, for example, through formation of local clusters, and "strategic coupling" of MNEs with regional networks within the value chain (Yeung, 2009; Young et al., 1994). Some supranational regions (such as the EU and North America) are often characterised by cross-border trade and investment agreements, which further enhances potential for profitable growth within these regions (Rugman and Verbeke, 2004). Operating across a larger context, such as a region, provides the firm with a better "learning experience", better chances of arbitrage and cross subsidization, and the ability to spread overhead costs (Qian et al., 2008). There is also emerging evidence that globalisation of value chains has a regional bias, at least in its individual components (Demirbag and Glaister, 2010; Mudambi and Puck, 2016), thus conferring region specific advantages where upstream activities are co-located with downstream ones.

Thus, from the firm's perspective, a country level focus results in an upper bound on the potential returns from scale and scope economies. At the same time, operating in widely disparate multiple countries puts a significant burden on coordinating and managing between several centres of operation. This leads to an increase in the liability of foreignness for the firm across many dimensions - cultural, financial and institutional. However, strategizing and operating at a regional level can reduce such liabilities, given the possibility of intra-regional synergies across the firm's value chain, implying that the liability of regional foreignness is likely to be lower than the liability of country level foreignness (Qian et al., 2013).

\section{Economic Growth and Regional Operations}

The question that naturally arises is whether the returns from operations within a region is uniform or can vary across regions? An important source of differences between regions is in their underlying economic growth. Countries within regions such as Asia-Pacific, especially its southern and eastern parts, have been characterized as countries that have enjoyed high rates of growth for several decades. Previous research has indicated that underlying economic fundamentals and the business environment, at least at local and national levels, do have an impact on firm profits (Gaganis et al., 2018; Hansen and Wernerfelt, 1989). Thus, regions composed of high growth countries provide a 
different operational context to firms (domestic ones and MNEs) operating within them, than those regions composed of slow growth countries.

Operating within relatively higher growth contexts provides specific advantages to firms. Firstly, it is expected that in such contexts, firms will be able to adapt their FSAs rapidly across national boundaries, for instance by imitating local competitors (Salomon and $\mathrm{Wu}, 2012$ ), and capitalizing on expanding markets. Expanding markets also provide firms with the room to find their own niche and cushion themselves against competition. They allow firms to diversify their offerings more easily, as the costs of failure of newly launched product offerings are relatively lower. Thus, establishing operations and expanding them within markets which are growing rapidly is expected to bring about greater marginal benefits than when doing the same in slower growing markets.

Benefits of high growth contexts are not just restricted to national economies but spill over into supranational regions as well, especially in the form of additional economies of scale and scope. Thus, operating within a faster growing region confers region-specific advantages to a firm, which not only helps it to overcome the compounded distance between the host and home regions but will contribute more towards overall performance than slow growing regions. The additional competitive advantage and economies of scale and scope conferred to the firm in a high growth region implies that an increment to operations or an additional sale made here will add more to profit than an equivalent sale in another region growing at a slower pace. This indicates that the degree of operations (which we define as sales within the region as a proportion of overall global sales) in the high growth region has a greater impact on performance than the degree of operations in a low growth region.

This leads to our first hypothesis:

H1: The underlying economic growth of a region positively moderates the linkage between the degree of operations and firm performance, that is, the incremental impact of the degree of operations within specific regions on firm performance will be greater in regions experiencing high growth rates.

The downstream operational characteristics of a firm within a region is not just limited to the amount of sales but also the rate at which the sales have been changing over time in the same region. This is conceptualized as the speed of operations by Chetty et al. (2014), and is considered to be an important feature of a MNE's operations internationally (Bowen et al., 2007; Hilmersson and Johanson, 2016; $\mathrm{Li}$ and $\mathrm{Li}, 2007)$. For instance, Barkema and Drogendijk (2007) and Chang and Rhee (2011), find that under a wide range of circumstances, rapid internationalization may be more beneficial to MNEs than internationalization using incremental steps. Mohr et al. (2014) find that internationalization speed positively moderates the positive link between home region concentration and performance. While the relationship between speed of internationalization and performance is likely to be non-linear, especially in the long run, firm level factors such as technological knowledge and internationalization experience can also change its characteristics (García-García et al., 2017) Thus, speed is increasingly 
being seen as a key strategic factor to consider when expanding internationally (Chetty et al., 2014; Li, 2007).

However, rapid expansion of operations can have a negative influence on performance (Barkema and Drogendijk, 2007; García-García et al., 2017). There is growing recognition of the dangers of MNEs "overstretching" themselves in their foreign operations. It has been pointed out that when the firm faces "bounded rationality" and "bounded reliability" challenges in non-home regions, this may lead to overestimation of its non-location bound FSAs (Verbeke and Asmussen, 2016), leading to a negative impact on performance, at least until the firm takes corrective action. One source of overstretching potentially lies in the speed of operations in a region, arising out of an over-optimistic view of its market potential (bounded rationality) or through underestimation of resources required to fully exploit the firm's FSAs (bounded reliability). Prior research shows that speed of operations generally has an inverted U-shaped relationship to performance in the context of entry into foreign markets (Powell, 2014; García-García et al., 2017).

The speed of operations takes on a bigger role at the regional level, as the liability of regional foreignness is usually lower than the liability of country foreignness due to the additional economies of scale and scope, and greater homogeneity across national borders (Qian et al., 2013). Firms that expand their operations rapidly in a fast-growing market are able to enjoy the advantages of being the first movers in niches yet to be explored by local competitors. In particular, a dynamic environment has been shown to be conducive to reaping first mover advantages (Frynas et al., 2006; Suarez and Lanzolla, 2007). Fast growing regions offer advantages to MNEs that are able to expand their operations relatively rapidly for several reasons. Expanding operations at a fast rate within a growing region would help an MNE to pre-empt scarce resources (Suarez and Lanzolla, 2007), become part of local networks which enhances economies of scale (Katz and Shapiro, 1992), and hence limits the rate at which competitors enter (Pfeffer and Salancik, 1978). Thus, MNEs expanding operations rapidly in a fast-growing region will be able to obtain a significant share of the market and at the same time make it more difficult for competitors, whereas these advantages will not be available, at least not to the same extent, for rapidly expanding firms in a slow growth region.

This discussion leads to the second hypothesis.

H2: The underlying economic growth of a region positively moderates the linkage between the speed of operations and firm performance, that is, the incremental impact of the speed of operations within specific regions on firm performance will be greater in regions experiencing high growth rates.

While expansion into foreign territory reflects the geographic diversity of a firm, diversity in its product offerings, within or across regions, provides a second source of strategic diversity (Geringer et al., 1989; Geringer et al., 2000). Geographic diversity, which is too ambitious in its spread or speed may result in overstretching, but it is not entirely clear how regional characteristics interact with 
overall diversity in a firm's product portfolio. Verbeke and Asmussen (2016) point out that a promising line of research is the potential trade-off between geographic diversity of a firm versus its product diversity. We now examine this potential trade-off and explore the role of product diversity in the context of region-specific expansion.

\section{Product Diversity and Regional Operations}

Product diversity has an important strategic role when MNEs expand their operations outside their home territory (Hitt et al., 1997; Oh and Contractor, 2012 and 2014). Although the direct impact of product diversity on performance has been studied extensively in the literature (Kirca et al., 2011), it is its indirect role as a moderator in the internationalization - performance link which is relevant for a MNE's international operations. Hitt et al. (1997) find a positive impact on performance of product diversity of internationally diversified firms, although Geringer et al. (2000) and Tallman and Li (1996) are not able to establish a link. Interestingly, Chan et al. (1989) find that product diversity matters only for firms whose geographic diversity is low. These results point towards a moderating role of product diversity on the link between internationalization and performance.

The moderation effect may be a result of several underlying mechanisms. An effective strategic response to local market conditions within the host country, in the form of new product offerings, results in a firm being able to exploit local advantages more effectively, leading to greater competitiveness relative to incumbents as well as potential entrants (Hitt et al., 1998; Sanchez, 1995). However, where the development of new products requires the utilization of key resources which are different from the firm's existing set of capabilities (Oh and Contractor, 2014), the benefits of expanding international operations will be dampened. Further, if product diversification is carried too far or too rapidly, there is the risk of overstretching beyond the firm's capabilities, thus negatively impacting the positive benefits of international operations. Building a large global product portfolio involves managing a complex global supply chain, which can support both major and minor product variations within and across regions (Brandon-Jones et al., 2014). Thus, managing the portfolio may also result in coordination problems between the firm's central and regional headquarters and its subsidiaries (Christopher and Lee, 2004).

These issues, while pertinent at the host country level, may be compounded at the regional level. A regional market, by definition, is larger and more complex in character, given the variety of tastes and preferences across a typical region. As a result, the risk of overstretching and coordination problems are greater for firms which are rapidly expanding their product portfolios in foreign regions. Oh and Contractor $(2012,2014)$ point out that in the home region and in regions which are closer to home, where firms enjoy positive returns from internationalization, increasing product diversity may act as a negative moderator as firms need to diversify into "unrelated" products, which share fewer common inputs and hence require additional resources and capabilities. They also argue that the opposite is 
true for regions further away from the home region, where the impact of internationalization is negative: When firms can access novel knowledge, generate new ideas, and take advantage of increased arbitrage opportunities between the home base and the foreign region (Ghemawat, 2001), they gain an advantage with greater product diversity. However, Oh and Contractor's argument considers the dichotomy between home versus non-home regions, without consideration of interregional differences. Firms with high product diversity that are expanding operations and doing so rapidly, tend to incur high transaction costs anyway (Batsakis and Mohr, 2017), so the negative impact is expected to be stronger in regions where the returns from operations are lower. This is because greater product diversity adds to the overall coordination burden of the MNE, and consequently to its transaction costs, thus reducing the positive impact of expanding operations or increasing the speed of operations. It follows that product diversity should act as a negative moderator, i.e. worsen the link between regional operations (degree and speed) and performance. This is expressed in the following hypothesis.

H3: Product diversity negatively moderates the linkages between the degree and speed of operations and firm performance, in the sense that, incremental benefits from degree and speed of operations will be less for firms with greater product diversity.

\section{Research Methods}

We obtained firm level panel data on regional expansion, performance and product offering from the Osiris database available at the Bureau van Dijk ${ }^{2}$. The unbalanced panel used for the analysis covers 1249 US based firms and all their international subsidiaries, for the years 1996 to 2005. For each firm, we collected the following information for each year in the time frame: domestic sales, international sales by region, sales by product variant, performance, plus other firm level factors such as number of employees, assets and number of subsidiaries.

The database provided detailed information of operations at both the country and supra-national levels. Given the focus of this paper, we aggregated operations of each firm to the regional level, where the regions considered are: domestic USA and all its territories (the home region, labelled as Region 1); Europe defined as EU and other countries within continental Europe (labelled Region 2), the Americas - excluding the USA (labelled Region 3), and the Asia-Pacific including mainland Asia and the Pacific rim (labelled Region 4). The database allowed us to categorise another region, covering Africa and Rest of the World (Region 5), distinct from Regions 1 to 4. However, given that

2 Further information about the general database can be found here: http://www.bvdinfo.com/en-gb/ourproducts/company-information/international-products/osiris . 
more than $95 \%$ of the firms in the database did not have operations there in the given time span, we have excluded it from our analysis ${ }^{3}$.

Table 1 presents the distribution of operations of the firms in our sample within Regions 1 - 4, along with the relevant categorical dummies. The dummy variables $D_{1}, \ldots, D_{7}$ represent the extent of foreign region coverage of a firm, while those operating purely within the home region are considered as the reference category. Note that a firm can operate in more than one region, and the categories themselves are exclusive of each other.

\section{[Insert Table 1 around here]}

Given the nature of the panel, the primary estimation strategy was to adopt the lagged "between" panel estimator using OLS, which captures most of the variation across the cross-section and partial variation over time. We explain the choice of this estimation strategy in more detail below, following the description of the independent, dependent and control variables.

\section{Independent Variables}

\section{Degree of operations}

The degree of operations in a region is defined as the sales of the MNE and its subsidiaries within the region as a proportion of total global sales. For any region $k$ and year $t$, this is estimated as an index

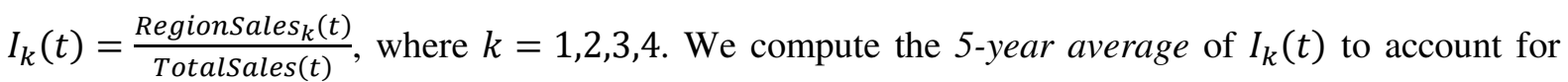
autocorrelations, year-to-year random variations and random missing data points. Since the data spans the years 1996 to 2005, we use the first 5 years of the data (1996 to 2000) to compute the degree of operations

$$
\operatorname{avg} I_{k}=\frac{1}{5} \sum_{t=1996}^{2000} I_{k}(t)
$$

for all regions $k=\{1,2,3,4\}$. This yearly average for the first five years in the data allows us to use a lagged specification in the regressions, which has benefits of reducing endogeneity through reverse causality (discussed in more detail below). Note that $0 \leq I_{k}(t) \leq 1$, implying that $0 \leq \operatorname{avg} I_{k} \leq 1$. A value close to 0 for region $k$ for an MNE, implies a low degree of operational presence in the region, whereas a value close to 1 implies that most or all of the MNE's downstream global sales are based

3 Regional classification is a key element of internationalization research (Flores et al., 2013). Ohmae (1985) introduced the notion of a "Triad" involving North America, Western Europe and Greater Japan as key global regions, which attracted most MNE activity. In our case, we let the Osiris data set define the regions, based on the company and subsidiary specific descriptions available in the data. These descriptions often overlapped and sometimes conflicted with each other. For consistency, we arrived at the five regional groups based on the common denominators among all descriptors. Ideally, one would use finer grained regional groupings, but the dataset only allowed us to use the five mentioned above. 
within the region $k$. Given our regional definitions, and the fact that the firms in our data are US based firms, $\operatorname{avg} I_{2}, a v g I_{3}, a v g I_{4}$ are the host region degrees of operations, while avgI $I_{1}$ represents the home region.

\section{Speed of operations}

Speed of operations within a region is defined as the rate of change of an MNE's degree of operations within the region. Thus, the index of speed of operations in region $k$ is estimated directly from the degrees of operations $I_{k}(t)$ as,

$$
\Delta \operatorname{avg} I_{k}=\frac{1}{4} \sum_{t=1997}^{2000}\left\{I_{k}(t)-I_{k}(t-1)\right\}
$$

for all regions $k=\{1,2,3,4\} . \Delta a v g I_{k}$ represents the average year to year change in the degree of operations in region $k$, and given that each term in the expression above represents the difference in an index between two consecutive years, also measures the rate of change. Thus, for any MNE, $\Delta a v g I_{k}$ measures the average speed at which its sales-based operations have expanded or contracted within region $k$. Note that $-1<\Delta a v g I_{k}<1$, where negative values represent contraction of operations, positive values represent expansion of operations, and the absolute value represents the rate of change.

\section{Product diversity}

Following previous literature, product diversity of a firm per year $t$ is measured by the well-known Herfindahl diversity index,

$$
p d(t)=1-\sum_{d}\left(\frac{\text { Sales }(d, t)}{\text { TotalSales }(t)}\right)^{2}
$$

where $\operatorname{Sales}(d, t)$ represents the global sales of variant $d$ in year $t$ and TotalSales $(t)$ represents overall global sales of the MNE in the same year. The independent variable used in the models is the 5 -year average $(\operatorname{avg} P D)$, once again for the first 5 years in the data:

$$
\operatorname{avg} P D=\sum_{t=1996}^{2000} p d(t)
$$

\section{Dependent Variable}

The dependent variable is average profit margin avg $\Pi$ which is computed using the last five years in the data (2001 to 2005), 


$$
\operatorname{avg} \Pi=\sum_{t=2001}^{2005} \Pi(t)
$$

where, $\Pi(t)$ represents the yearly profit margin for year $t$.

This provides a lagged specification in the models, which minimizes reverse causality problems between the dependent and independent variables.

\section{Controls}

The degree of domestic operations $\left(a v g I_{1}\right)$ is used as a control variable in the analysis as the focus of this paper is on host region operations. The product diversity index ( $\operatorname{vvgPD})$ is also treated as a control, while the specific interaction terms between $\operatorname{avgPD}$ and independent variables are part of the set of independent variables. Additional controls used in the analysis are: total assets, number of employees and number of subsidiaries, from the year 2005, all normalized within 0 and 1 . The set of dummies $D_{1}, \ldots, D_{7}$ are used to control for geographic coverage of the MNEs, given that international experience and scope has been shown to impact returns from internationalization. The literature also uses additional controls, wherever they are available, when carrying out firm level analysis. Variables such as leverage ratio, firm age, and marketing spend would all have been appropriate, but we did not have access to additional controls. R\&D intensity was available but only for a small proportion of the firms in the sample (approximately 20\%), and hence not included.

Descriptive statistics and cross correlations of all independent and control variables are presented in Tables 2 and 3 respectively. Note that apart from the relatively high correlations between $\operatorname{avg} I_{k}$ and $\Delta a v g I_{k}(k=2,3,4)$, which are never used as covariates in the same model, the rest of the correlations are low or are not significant.

[Insert Table 2 around here]

[Insert Table 3 around here]

\section{Models and Methods}

We estimate the following linear regression models, using the OLS estimator.

Model 1:

$$
\begin{aligned}
& \operatorname{avg} \Pi=\alpha^{1}+\sum_{j=2}^{4} \beta_{j}^{1} \operatorname{avg} I_{j}+\sum_{j=2}^{4} \delta_{j}^{1}\left(\operatorname{avgI} I_{j} \times \operatorname{avgPD}\right)+\sum_{j=1}^{7} z_{j}^{1} D_{j}+z_{8}^{1} \operatorname{avg} I_{1}+z_{9}^{1} \operatorname{avg} P D \\
& +z_{10}^{1} \text { assets }+z_{11}^{1} \text { employees }+z_{12}^{1} \text { subsidiaries }+u^{1}
\end{aligned}
$$


Model 2:

$$
\begin{aligned}
& \operatorname{avg} \Pi=\alpha^{2}+\sum_{j=2}^{4} \beta_{j}^{2} \Delta a v g I_{j}+\sum_{j=2}^{4} \delta_{j}^{2}\left(\Delta a v g I_{j} \times \operatorname{avgPD}\right)+\sum_{j=1}^{7} z_{j}^{2} D_{j}+z_{8}^{2} a v g I_{1}+z_{9}^{2} \operatorname{avg} P D \\
& +z_{10}^{2} \text { assets }+z_{11}^{2} \text { employees }+z_{12}^{2} \text { subsidiaries }+u^{2}
\end{aligned}
$$

In Model 1, the key independent variables are the degrees of regional operations $\left(\operatorname{avg} I_{j}\right)$, and in Equation 2 it is the speed of regional expansion $\left(\Delta a v g I_{j}\right)$. For both Models, $D_{1}, \ldots, D_{7}, \operatorname{avg} I_{1}$, avgPD, assets, employees, subsidiaries control for a firm's international experience, operations within the domestic market, product diversity, asset holdings, number of employees, and number of subsidiaries respectively. Given the non-linear M-P relationships presented in previous research, we also included the impact of square terms for $\operatorname{avg} I_{j}(j=2,3,4)$ in both models.

To test $\mathrm{H} 1$ and $\mathrm{H} 2$, we examine the coefficients of $a v g I_{j}$ and $\Delta a v g I_{j}$ respectively, each of which represents the incremental impact of operations and speed in a given host region $j$, where $j=2,3,4$. Table 4 presents the key facts about the growth rates of Regions 2, 3 and 4 over the last five decades (IMF World Economic Outlook and World Bank). Thus Region 4 (Asia-Pacific) was the fastest growing region in the period 1996-2005, followed by the Americas (Region 3), while Europe was the slowest among the three. Given that the marginal impact of operations in each region is estimated independently, significant differences in the coefficients corresponding to the three regions indicate the difference in impact of operations within them. At the same time, any consistent alignment of the absolute values of the coefficients with the regional growth rates themselves would be indicative of a moderation effect - although we cannot claim that it is a causal relationship. To test H3, we examine the coefficients of the interaction terms in Models 1 and 2 directly. ${ }^{4}$

[Insert Table 4 around here]

The OLS model specification described above, is the lagged between estimator for panel regressions, which exploits the cross-sectional dimension of the data by using the averages of independent and dependent variables. The time dimension is captured partially through the lagged specification.

\section{Choice of Estimator, Robustness and Endogeneity}

\footnotetext{
$4 \quad$ Our analysis does not adopt a multi-level approach, in the sense that we do not consider firms from multiple countries and do not explicitly account for foreign region differences. The reasons are two-fold. First, country level explanatory variables would make the model very complex, diluting the central message of our analysis. Using firms from one country, we can bypass this complexity and concentrate on inter-regional heterogeneity, as applicable for US firms. Second, incorporating host region characteristics within the models would require a completely different empirical specification. The former would require simultaneous estimation of region level performance models, which would in turn require further fine tuning of regional definitions, additional data and metrices of regional indicators.
} 
Estimators exploiting the time dimension fully (such as two-way Random and Fixed Effects) were not used as the main estimation strategy due to the following reasons. First, missing values for some random years within the time variant variables (product diversity, employees, subsidiaries) for some firms, implied a lower number of observations were being used in the corresponding Random and Fixed effect estimates. Second, given that the panel was highly unbalanced with only 10 time periods, fully specified Random effect models could not be estimated due to the absence of sufficient degrees of freedom. However, as part of robustness checks on the analysis, we did estimate lagged two-way Random and Fixed effect models for Equations 1 and 2 within complete sub-samples without any interaction terms. Whether the Random or the Fixed effect results was appropriate for Models 1 and 2, was determined using the Hausman-Wu test.

The independent and dependent variables were $\Pi(t)$ and $I_{k}(t-1)$ for $k=2,3,4$. For Random effects models, the controls included were the time variant ones $I_{1}(t-1)$ and $p d(t-1)$, as well as all the time invariant ones used in the "between" analysis. For Fixed effects, only time invariant controls were included along with firm specific dummies controlling for static heterogeneity. The results, reported in Table 7, are largely in line with our main findings (Tables 5 and 6) with respect to differences in the impact of regional operations. However, it is important to remember these do provide an additional level of robustness check and a useful benchmark, the interpretation of the equivalent coefficients in Table 7 are qualitatively different from those in Tables 5 and 6 , as the former capture intra-firm effects whereas the latter is concerned with inter-firm differences.

At the same time, the between estimator provided a better overall model fit, and allowed the introduction of a full set of independent variables and interaction terms without restrictions on degrees of freedom. Also, we could see that the explained variance across firms was far higher than the explained variance over time for the two-way models (see Table 7 diagnostics of Equation 1 estimates). Thus, the use of the between estimator, which could fully exploit this variation, was deemed appropriate.

As with any analysis which relies on cross section analysis, endogeneity is possible, particularly with regard to the exogenous nature of $a v g I_{k}$. However, the use of the lagged specification - where the independent variables are constructed using the 1996-2000 data and dependent variable is constructed using the 2001-2005 data - reduces the chance of reverse causality significantly. We cannot rule out endogeneity through unobserved heterogeneity among the firms, although the residual diagnostic tests in the OLS models do not point towards any major issues.

Several additional steps were undertaken to ensure robustness of our results. First, besides using average profit margin as the key dependent variable, we also tested the models with similar measures constructed from EBITDA and ROI. Both yielded results consistent with profit margin, and the latter was eventually chosen given its distributional characteristics. Second, for every model estimated, we 
carried out a set of diagnostic and visual checks on the model residuals to test for white noise, leverage, influence of outliers and heteroscedasticity. The estimates passed all the tests without any major issues.

\section{Results}

The main results from the OLS based "between" estimates are presented in Tables 5 and 6, while the supporting benchmarks and robustness tests using the Fixed and Random effects estimators are presented in Table 7. A summary of the findings in terms of Hypotheses 1, 2 and 3 are provided in Table 8. All inferences are made using heteroscedasticity-robust (White-Huber) standard errors. Moderation effects of $\operatorname{avgPD}$ are tested through the interaction with $a v g I_{k}$ in the between estimates, and graphs of significant interaction effects are presented in Figures 1-3. These show the impact of the main covariates (degrees and speeds of operations across regions 2, 3 and 4) on the dependent variable - for the lower and upper bounds of the product diversity index.

Among the controls, the home region operations $\left(a v g I_{1}\right)$ always has a large and positive impact on performance. The impact of avgPD is also positive and significant for the between estimates, implying that firms with greater diversity in their product portfolios perform better overall. Size of the firm matters to an extent, in particular employees has a consistent positive impact, but not subsidiaries and assets. Finally, within the regional coverage dummies, only $D_{4}$ shows a positive effect, indicating that US firms which have internationalized into both EU and Latin America show higher profitability on average than firms with alternative international coverage patterns. ${ }^{5}$

We next examine the impact of the main independent variables and relevant interaction terms. Note that the coefficients of interest represent the incremental impact of the variables $a v g I_{j}$ and $\Delta a v g I_{k}$, that is, the impact on overall profitability for a small increase in degree and speed of operations, in region $j$, and not the profits arising from the region itself, which we cannot estimate.

\section{Degree of Operations and Product Diversity (Model 1)}

All results pertaining to Model 1 are presented in Table 5. In Model 1a, the regression includes only the main effect of regional operations $\left(\operatorname{avg} I_{k}, k=2,3,4\right)$, while the interactions of product diversity with $\operatorname{avgI} I_{2}, \operatorname{avg} I_{3}$, and $\operatorname{avgI}_{4}$ are introduced in Models $1 \mathrm{~b}, \mathrm{c}$ and $\mathrm{d}$. None of the non-linear square terms of $a v g I_{k}$ were significant in any of the models and results remained unchanged. Hence, to

$5 \quad$ A slight discrepancy exists among the sign of the coefficients of some controls (avgPD and assets) in the "between" estimates of Tables 5 and 6 with the Random and Fixed effects estimates of Table 7. This is primarily due to the fact that Table 7 coefficients measure the average dynamic impact of the time varying variables "within" a firm, when cross section effects are controlled for. However, the "between" estimator measures the impact across firms, when variations across time within a firm are partially controlled for. This distinction is crucial for time varying variables such as avgPD. 
economize on space and to reduce the complexity in the interpretation of the interaction terms, we reestimated the models by excluding the square terms.

\section{[Insert Table 5 around here]}

Results reveal that for expansion in the four specific regions defined in our data, only the degree of operations in Region 4 (Asia-Pacific) has a significant and sizable direct positive impact on a firm's profit margin, which is larger than the home country impact (coefficient size of 96.40 in case of avgI vs 52.81 for $\left.a v g I_{1}\right)$ in Model 1a. There is no evidence of any direct impact of operations in Regions 2 and 3 in Model 1a. Thus, degree of operations within the fastest growing region has a strong positive impact on performance, which is not seen in the case of the slow growth regions, supporting H1.

However, the full picture becomes more complex for the slow growth regions once product diversity is accounted for. When the interactions with $\operatorname{avg} P D$ are introduced, the coefficients of $a v g I_{2}$ and avgI $I_{3}$ become significant and positive in Models $1 \mathrm{~b}$ and $1 \mathrm{c}$ respectively. For firms with low values of $\operatorname{avgPD}$, the coefficients of $a v g I_{2}$ and $a v g I_{3}$ are large, positive and significant (124.75 and 206.21 respectively), implying firms with relatively low levels of product diversity benefit from increasing operations in Regions 2 (Europe) and 3 (Americas). These coefficient sizes are quite large in magnitude, significantly larger than those of domestic operations and Region 4 operations. However, the net impact turns negative for higher values of $\operatorname{avgPD}$ (see Figures 1 and 2). Thus, product diversity acts as a negative moderator in the operations - performance relationship, but only for Regions 2 and 3. No evidence of such an interaction with avgI $_{4}$ could be found, implying that for Region 4, product diversity does not impact the already strong operations - performance linkage. This implies we have partial evidence in support of $\mathrm{H} 3$, which stated a negative moderation effect irrespective of the region.

It is interesting to note that for high values of avgPD only, the net impact of operations in Regions 2, 3 and 4 are $-353.19,-168.19$ and 0 (obtained by adding the coefficients of $\operatorname{avg} I_{k}$ and $\operatorname{avg} I_{k} *$ $\operatorname{avgPD}$ ). The ordering once again supports $\mathrm{H} 1$, implying that the hypothesis is generally seen to be confirmed except under the condition of low values of product diversity.

[Insert Figures 1 and 2 around here]

\section{Speed of Operations and Product Diversity (Model 2)}

All results pertaining to Model 2 are presented in Table 6. In Model 2a, the regression includes only the main effect of the speed of operations $\left(\Delta a v g I_{k}, k=2,3,4\right)$, while the interactions of product diversity with $\Delta a v g I_{2}, \Delta a v g I_{3}$ and $\Delta a v g I_{4}$ are introduced in Models $2 \mathrm{~b}, \mathrm{c}$ and d. Once again, no impact of the non-linear square terms was detected, and hence were excluded to reduce complexity in the models. 
[Insert Table 6 around here]

We observe strong evidence of a large positive impact of the speed of operations in Region 4 (significant positive coefficient of 275.18 of $\Delta a v g I_{4}$ ). As in the case of the degree of operations, we do not detect a significant direct impact of speed of operations in Regions 3 and 4. Thus, speed of operations within the fastest growing region has a strong positive impact on performance, which is not seen in the case of the slow growth regions, supporting $\mathrm{H} 2$.

However, in the case of Region 2, the impact of speed of operations is once again conditional on product diversity, as evidenced from Model $2 \mathrm{~b}$. For low levels of product diversity, the incremental impact of speed in Region 2 is positive and large (252.93), but the net impact once again turns negative for higher levels of $\operatorname{avgPD}(-1005.67)$, as seen from the coefficient of the interaction term in Model 2b (and Figure 3). The difference with Model 1 lies in Region 3. Neither the speed nor its interaction with product diversity appears significant for Region 3 (Models 2a and c). Finally, we see no interaction between speed of operations in Region 4 and $\operatorname{avg} P D$, implying that the strong positive impact of growing operations in Region 4 is unaffected by the firm's product diversity.

Thus, we find some evidence in support of $\mathrm{H} 3$, but it is weaker than its counterpart in the degree of operations.

\section{[Insert Figure 3 around here]}

\section{Robustness and Time Varying Effects}

The two way Fixed and Random effect estimates capturing the dynamic dependence of performance on regional operations "within" the average firm, may be used as a benchmark for evaluating the "between" estimates based on cross sectional variation. As can be seen from Table 7, these results mirror those presented as Models 1a and 2a in Tables 5 and 6 respectively, conditioned on the differences in interpretation between the two. First of all, incremental operations (both degree and speed) in Region 2 has an unequivocal large negative impact on future performance of a firm (coefficients of -10.33 and -21.35 for $I_{2}$ and $\Delta I_{2}$ respectively). Secondly, the degree of operations has a large significant positive impact on future performance in Region 4 (coefficient of 5.70 of $I_{4}$ ), and a negative impact in Region 3 (coefficient of -9.63 of $I_{3}$ ). No direct impact of speed of operations in Region 3 and 4 could be detected.

These results point towards two things. First, MNE operations within the slowest growing Region 2 has a direct negative impact, and as far as the degree of operations is concerned, the fastest growing Region 4 has a direct positive impact on future performance of the MNE. Second, as the diagnostics indicate in the Random Effects model, intra-firm variation is very low over the 10 year period under consideration, and possibly longer time periods are required to pick up further dynamic effects. 
Before moving to the next section, we provide a summary of the overall results in terms of support for our hypotheses in Table 8.

[Insert Table 8 around here]

\section{Discussion}

Although the international business literature has increasingly focussed on the impact of regionalization (Chakravarty et al., 2017; Mahnke et al., 2012; Rugman, 2005), there have been calls for further exploration of the regional dimension in terms of MNE performance and strategy (Nguyen, 2017; Verbeke and Asmussen, 2016). We have addressed this call and made the following contributions: (1) we show that the performance impact of downstream operations (degree and speed) in supra-national regions varies from region to region; (2) the differences in impact coincides with the underlying economic growth of the regions themselves and (3) for slow growing regions, product diversity is an important strategic instrument for MNEs operating there, while this is less the case for faster growing regions. The emerging picture of impact of regionalization is noteworthy and complex, and the results enrich our understanding of how a regional strategy, as opposed to a global strategy, impacts MNE performance.

From a theoretical perspective, the first key finding concerning inter-regional differences shows that a simple dichotomy between the home and foreign region, previously widespread in the internationalization-performance literature, is an over-simplification (Nguyen, 2017; Qian et al., 2010; Yang et al., 2013). While extant research is yet to settle the question of the impact of international operations on performance, the complex picture that emerges from our analysis shows that the overall link between the two is possibly a combination of several individual region-specific relationships, with additional confounding strategic factors, such as product diversity, and environmental factors, such as regional economic growth. At the same time, the absence of a non-linear impact of individual regionspecific operations on overall performance shows that once regions are considered as the locus of internationalization, the scale diseconomies which are apparent at the host country level become less significant. Thus our work not only emphasizes the importance of the regional focus as the way forward in international business research, in line with recent literature (Arregle et al., 2013; Chakravarty et al., 2017; Verbeke and Asmussen, 2016), but quantitatively addresses the importance of region specific operational characteristics and the differences between these with regard to the impact on performance, a topic which has not been addressed previously.

This has implications not just for the theory, but also the practise of internationalization. A regional focus, where operationalization with each region is considered autonomously by relevant managers, reduces the MNE's managerial constraints of bounded rationality and reliability (Verbeke and Asmussen, 2016). If resources available to the management are fixed in the short term, knowing 
which regions are potentially more valuable for future investments in functions such as marketing, distribution and retail, would enable the MNE to allocate its resources optimally. Similarly, being aware regionally of where diversity in the MNE's product portfolio may impact its returns negatively would enable the MNE to be more efficient. Finally, given the significant economies offered within a region as opposed to outside it, the actual country where the firm operates from would matter less than the choice of the region itself. At the very least, the management's choice of the host country may be considered a "second order" choice with the host region itself being the "first order" choice. Thus, our research points towards ways of economizing on the resources of the firm on one hand, and on reducing the burdens of rationality and reliability for the management on the other.

The second key finding stresses that differences between regions in terms of the impact of degree and speed of operations on performance may be traced to the underlying economic growth rates of these regions. Table 3 shows that on average between 1980 and 2010, Asia-Pacific has been the fastest growing region, followed by Europe and the Americas at a significant distance. Africa and the rest of the world lagged significantly behind the others barring the last few years. When compared to the results of Table 5, we see that the marginal returns from operations in Asia-Pacific have also been the highest for US MNEs, with very little overall impact of the other regions. The latter result changes when moderation of product diversity is introduced (which we discuss later). The results are similar when the speed of operations is considered (Table 6), with once again the fastest growing MNEs benefitting the most from Asia-Pacific operations compared to other regions. While our analysis does not reveal a direct causal link between regional growth and the performance impact of operations in the region, the alignment between the two is quite stark. Note that the regional economic growth ceases to be a factor for the home region, in this case the US territories themselves, as home region advantages (familiarity, experience, access to resources, networks, etc.) supersedes the advantages underlying economic growth may confer on the MNE.

It is instructive to examine the possible link between growth rates and firm performance in further detail. Consider the case of Europe (Region 2), which is generally accepted as being culturally, institutionally and economically closer to the US compared with the Asian or Latin American countries (Gupta et al., 2002). It is also accepted that the institutional framework in Europe is stable and favourable for business ${ }^{6}$. In spite of these apparent advantages, we find expansion within the slow growing European region resulted in lower marginal returns to US firms, compared to expansion within the fast growing Asia-Pacific. The Asia-Pacific region is composed of countries which have provided access to valuable skills and capabilities (Guillen, 2000), access to growing markets and increasingly liberalised economies. Countries in these regions have also experienced structural, trade

$6 \quad$ The World Bank's "Doing Business 2017" report, available from http://www.doingbusiness.org/reports/global-reports/doing-business-2017. 
and economic reforms, which have led to sustained inflow of FDI during the study period (Alguacil et al., 2011). At the same time offshoring and outsourcing have grown significantly for many countries in these regions (Demirbag and Glaister, 2010; Lewin and Peeters, 2006).

To establish a direct causal link between growth rates and firm performance would require detailed micro and macroeconomic regional panel data, which would control for other factors, but which is beyond the scope of this study. At the very least, we establish that MNEs' performance is boosted more from operations within high growth supra-national regions than from operations in low growth regions. Furthermore, in a significant modification to the existing views on FSAs and home region advantage (Banalieva and Dhanaraj, 2013), this points towards "location boundedness" of FSAs taking on new meaning outside the home region, especially when combined with region specific advantages such as underlying economic fundamentals. From a managerial perspective, it also implies a degree of flexibility available to the organization in terms of resource allocation. The quantity and nature of resources provided to a region may be allocated by the central management based on economic fundamentals, but once allocated, the regional management can be allowed to distribute them efficiently based on local knowledge and needs. These findings also call for new research into the pathways through which underlying regional fundamentals translate into returns from operations within a region, which goes beyond the traditional distance related or institutional views of host nations.

The third key finding is that product diversity negatively moderates the link between regional operations and performance in low growth regions, but not in high growth ones. This result builds on a substantial body of literature which has emphasized linkages between internationalization, performance and product diversity (Oh and Contractor, 2014; 2012; Varadarajan and Ramanujam, 1990). Considering a simple home versus foreign region dichotomy, prior research has shown that geographic diversity coupled with product diversity improves performance. We extend this by deconstructing the heterogeneous impact of product diversity across different host regions. Within slow growing regions, where marginal returns from operations are low, high product diversity dampens the marginal impact of operations on performance, whereas no such effect is detected in high growth regions. This can be directly related to additional transaction costs of increased product diversity (Batsakis and Mohr, 2017), but is relevant only for slow growth regions. It can be assumed that high marginal returns from operations in high growth regions subsume any negative effects of transaction costs arising from coordination issues. This is a significant finding and provides opportunities for future research, examining the local and regional contexts in more detail. For instance, this finding opens up new avenues of research on how MNEs in order to improve performance may vary product diversity between regions based on regional characteristics, which is of both theoretical and practical importance. 
Interestingly, the absence of non-linear effects of both the degree and speed of regional operations implies that the upper limit for scope and scale economies is most likely very high when regions are the locus of expansion, rather than individual countries. This inference differs from the findings of Qian et al. $(2008,2010)$ because these authors considered the number of regions firms operated in as an indicator of regionalization, rather than the extent of operations in each region examined in this study. The fact that regions provide greater opportunities for exploiting economies of scale and scope, as well as relative ease of mobility of resources across national borders within the region, are potential reasons for the absence of the non-linear effects.

\section{Limitations and Conclusion}

While the study makes an important contribution to the literature on regionalization, it is not without its limitations. First, the data covers the years 1996 to 2005, and hence does not include more recent years. While this is a potential drawback, it is the case that this time frame represented a period of relative stability and growth in all the supra-national regions considered here. There were instances of macro shocks such as the East Asian financial crisis, the dot com bubble etc., but these were geographically and/or temporally localized. In contrast, the decade after 2005 was a period of both severe economic and political uncertainty, and witnessed significant technological innovations. Hence models incorporating data from this later period would need to account for structural breaks and shifts, making them more complex. Given the nature of the research questions addressed, the data from 1996-2005 allows us to carry out the analysis without having to be too concerned about major global events and structural shifts. Nonetheless, it would be instructive to undertake a similar exercise with more recent data, as this would facilitate examination of the nature and extent of any changes in the internationalization and regionalization strategies of MNEs.

Further limitations are that we consider only US firms, and we do not include regional economic characteristics directly within the analysis. To address these limitations would require a more complex multi-level analysis, which was not undertaken in this paper for two key reasons. First, using firms from several countries would require us to incorporate home and host regional characteristics and account for bi-directional linkages between regions. This would make the models very complex, diluting the central message of our analysis. By considering firms from one country, we are able to bypass this complexity and concentrate on inter-regional heterogeneity, as applicable for US firms only. Second, these more complex models would require a completely different empirical specification, such as simultaneous estimation of region level performance models, which in turn would require further fine tuning of regional definitions, additional data and metrics of regional indicators. Accounting for these was beyond the scope of this study but are important features which could usefully be examined in the future. 
Despite these limitations, we contribute to the literature by identifying the complex inter-relationship that exists between regional operations and firm level characteristics. Our findings reveal some of this complexity in terms of the heterogeneity between regions, the impact of regional operations and the interaction with product diversity. The study's findings show that product diversity is an important consideration for firms in their regional expansion plans, especially in the context of regions that are deemed less lucrative in terms of incremental sales.

Our findings indicate the key role played by specific (host) regions in the development of the firm's regionalization strategy. In particular, the underlying economic growth of the region provides advantages, as is indicated by the greater performance impact of the degree and speed of operations from these regions. However, this finding is indicative, and we cannot claim a causal linkage between the two. Uncovering the exact source of region-specific variations would entail employing multi-level models, which would account for region specific advantages including economic growth. At the same time, we accounted for product diversity as a firm level strategic factor which affects the regionalization - performance link. Future modelling exercises can and should incorporate other firm level information on asset distributions and organizational features, which were beyond the scope of this study. As this paper explores regional effects on a sample of US firms, it would be beneficial to investigate whether the effects reported here are similar for firms from a different home country or region. 


\section{References}

Alguacil, M., Cuadros, A. and Orts, V. (2011) 'Inward FDI and growth: The role of macroeconomic and institutional environment', Journal of Policy Modeling, 33(3), pp. 481-496.

Arregle, J. L., Miller, T. L., Hitt, M. A., and Beamish, P. W. (2013). 'Do regions matter? An integrated institutional and semiglobalization perspective on the internationalization of MNEs'. Strategic Management Journal, 34(8), 910-934.

Asmussen, C. G. (2009) 'Local, regional, or global? Quantifying MNE geographic scope', Journal of International Business Studies 40(7), pp. 1192-1205.

Asmussen, C. G. (2012). 'Foundations of regional versus global strategies of MNEs'. In Verbeke, A. and Hemant, H. (Eds), Handbook of Research on International Strategic Management. Cheltenham: Edward Elgar, pp. 271-90.

Asmussen, C. G., Larsen, M. M. and Pedersen, T. (2016) 'Organizational Adaptation in Offshoring: The Relative Performance of Home- and Host-Based Learning Strategies', Organization Science, 27(4), pp. 911-928.

Banalieva, E. R., and Dhanaraj, C. (2013). 'Home-region orientation in international expansion strategies'. Journal of International Business Studies, 44(2), pp. 89-116.

Barkema, H. G. and Drogendijk, R. (2007) 'Internationalising in small, incremental or larger steps?', Journal of International Business Studies, 38(7), pp. 1132-1148.

Batsakis, G. and Mohr, A. T. (2017) 'Revisiting the relationship between product diversification and internationalization process in the context of emerging market MNEs', Journal of World Business, 52(4), pp. 564-577.

Beugelsdijk, S. and Mudambi, R. (2013) 'MNEs as border-crossing multi-location enterprises: The role of discontinuities in geographic space', Journal of International Business Studies, 44(5), pp. 413426.

Brandon-Jones, E., Squire, B., Autry, C. W., and Petersen, K. J. (2014). 'A contingent resource-based perspective of supply chain resilience'. Journal of Supply Chain Management, 50(3), pp. 55-73.

Chakravarty, D., Hsieh, Y.-Y., Schotter, A.P.J. and Beamish, P.W. (2017) 'Multinational enterprise regional management centres: Characteristics and performance.' Journal of World Business 52(2), 296-311.

Chan Kim, W., Hwang, P. and Burgers, W. P. (1989) 'Global diversification strategy and corporate profit performance', Strategic Management Journal, 10(1), pp. 45-57. 
Chang, S.-J. and Rhee, J. H. (2011) 'Rapid FDI expansion and firm performance', Journal of International Business Studies, 42(8), pp. 979-994.

Chetty, S., Johanson, M. and Martín Martín, O. (2014) 'Speed of internationalization: Conceptualization, measurement and validation', Journal of World Business, 49(4), pp. 633-650.

Christopher, M. and Lee, H. (2004) 'Mitigating supply chain risk through improved confidence', International Journal of Physical Distribution \& Logistics Management, 34(5), pp. 388-396.

Contractor, F. J., Kundu, S. K. and Hsu, C.-C. (2003) 'A three-stage theory of international expansion: the link between multinationality and performance in the service sector', Journal of International Business Studies, 34(1), pp. 5-18.

Daniels, J. D. and Bracker, J. (1989) 'Profit performance: Do foreign operations make a difference?', Management International Review, 29(1), pp. 46-56.

Delios, A. and Beamish, P. W. (2005) 'Regional and Global Strategies of Japanese Firms', Management International Review, 45(1), pp. 19-36.

Demirbag, M. and Glaister, K. W. (2010) 'Factors Determining Offshore Location Choice for R\&D Projects: A Comparative Study of Developed and Emerging Regions', Journal of Management Studies, 47(8), pp. 1534-1560.

Elango, B. (2004) 'Geographic Scope of Operations by Multinational Companies:: An Exploratory Study of Regional and Global Strategies', European Management Journal, 22(4), pp. 431-441. Erramilli, M. K., Agarwal, S., and Kim, S. S. (1997). 'Are firm-specific advantages location-specific too?' Journal of International Business Studies, 28(4), pp. 735-757.

Flores, R., Aguilera, R., Mahdian, A. and Vaaler, P. (2013). 'How well do supranational regional grouping schemes fit international business research models?'. Journal of International Business Studies, 44, pp. 451-74.

Frynas, J. G., Mellahi, K. and Pigman, G. A. (2006) 'First mover advantages in international business and firm-specific political resources', Strategic Management Journal, 27(4), pp. 321-345.

Gaganis, C., Pasiouras, F., and Voulgari, F. (2018). 'Culture, business environment and SMEs' profitability: Evidence from European Countries'. Economic Modelling. In Press.

García-García, R., García-Canal, E. and Guillén, M. F. (2017) 'Rapid internationalization and longterm performance: The knowledge link', Journal of World Business, 52(1), pp. 97-110.

Geringer, M.J., Beamish, P. W. and Dacosta, R. C. (1989) 'Diversification strategy and internationalization: Implications for mne performance', Strategic Management Journal, 10(2), pp. 
$109-119$.

Geringer, J. M., Tallman, S. and Olsen, D. M. (2000) 'Product and international diversification among Japanese multinational firms', Strategic Management Journal, 21(1), pp. 51-80.

Ghemawat, P. (2001) 'Distance still matters', Harvard Business Review, 79(8), pp. 137-147.

Gomes, L. and Ramaswamy, K. (1999) 'An Empirical Examination of the Form of the Relationship Between Multinationality and Performance', Journal of International Business Studies, 30(1), pp. 173-187.

Guillen, M. F. (2000) 'Business groups in emerging economies: A resourced-based view', Academy of Management Journal, 43(3), pp. 362-380.

Gupta, V., Hanges, P. J. and Dorfman, P. (2002) ‘Cultural clusters: methodology and findings', Journal of World Business, 37(1), pp. 11-15.

Hansen, G. S. and Wernerfelt, B. (1989). 'Determinants of firm performance: The relative importance of economic and organizational factors'. Strategic Management Journal, 10(5), pp. 399-411.

Hennart, J.-F. (2011) 'A theoretical assessment of the empirical literature on the impact of multinationality on performance', Global Strategy Journal, 1(1-2), pp. 135-151.

Hilmersson, M. and Johanson, M. (2016) 'Speed of SME Internationalization and Performance', Management International Review, 56(1), pp. 67-94.

Hitt, M. A., Hoskisson, R. E. and Kim, H. (1997) 'International diversification: Effects of innovation and firm performance in product-diversified firms', Academy of Management Journal, 40(4), pp. $767-798$.

Hitt, M. A., Keats, B. W. and DeMarie, S. M. (1998) 'Navigating in the new competitive landscape: Building strategic flexibility and competitive advantage in the 21st century.', Academy of Management Perspectives, 12(4), pp. 22-42.

Katz, M. and Shapiro, C. (1992). 'Product introduction with network externalities', Journal of Industrial Economics, 40, pp. 55-83.

Kirca, A. H., Hult, G. T. M., Roth, K., Cavusgil, S. T., Perryy, M. Z., Akdeniz, M. B., and White, R. C. (2011). 'Firm-specific assets, multinationality, and financial performance: A meta-analytic review and theoretical integration'. Academy of Management Journal, 54(1), pp. 47-72.

Lasserre, P. (1996). 'Regional headquarters: The spearhead for Asia Pacific markets'. Long Range Planning, 29(1), pp. 30-37.

Lewin, A. Y. and Peeters, C. (2006) 'Offshoring Work: Business Hype or the Onset of Fundamental 
Transformation?', Long Range Planning, 39(3), pp. 221-239.

Li, L. (2007) 'Multinationality and performance: A synthetic review and research agenda', International Journal of Management Reviews, 9(2), pp. 117-139.

Lu, J. W. and Beamish, P. W. (2004) 'International diversification and firm performance: The S-curve hypothesis', Academy of Management Journal, 47(4), pp. 598-609.

Mahnke, V., Ambos, B., Nell, P. C., and Hobdari, B. (2012). 'How do regional headquarters influence corporate decisions in networked MNCs?' Journal of International Management, 18(3), 293-301.

Mohr, A., Fastoso, F., Wang, C., \& Shirodkar, V. (2014). 'Testing the Regional Performance of Multinational Enterprises in the Retail Sector: The Moderating Effects of Timing, Speed and Experience'. British Journal of Management, 25(SUPPL.1), S100-S115.

Mudambi, R. and Puck, J. (2016) "A Global Value Chain Analysis of the "Regional Strategy" Perspective', Journal of Management Studies, 53(6), pp. 1076-1093.

Nguyen, Q. T. K. (2017) 'Multinationality and Performance Literature: A Critical Review and Future Research Agenda', Management International Review, 57(3), pp. 1-37.

Oh, C. H. and Contractor, F. (2014) 'A Regional Perspective on Multinational Expansion Strategies: Reconsidering the Three-stage Paradigm', British Journal of Management, 25(S1), pp. S42-S59.

Oh, C. H. and Contractor, F. J. (2012) 'The role of territorial coverage and product diversification in the multinationality-performance relationship', Global Strategy Journal, 2(2), pp. 122-136.

Ohmae, K. (1985). ‘Triad Power: The coming shape of Global Competition'. New York: Free Press. Pfeffer, J. and Salancik, G.R. (1978) 'The external control of organizations'. New York: Harper and Row.

Powell, K. S. (2014) 'Profitability and Speed of Foreign Market Entry', Management International Review, 54(1), pp. 31-45.

Qian, G., Li, L., Li, J. and Qian, Z. (2008), 'Regional diversification and firm performance', Journal of International Business Studies, 39 (2), pp. 197-214.

Qian, G., Khoury, T.A., Peng, M.W. and Qian, Z. (2010) 'The performance implications of intra- and interregional geographic diversification', Strategic Management Journal, 31 (9), pp. 1018-1030.

Qian, G., Li, L. and Rugman, A. M. (2013) 'Liability of country foreignness and liability of regional foreignness: Their effects on geographic diversification and firm performance', Journal of International Business Studies, 44(6), pp. 635-647. 
Ral-Trebacz, A. and Eckert, S. (2016) 'Performance effects of intra- and inter-regional expansion: The moderating role of firm-specific advantages', Problems and Perspectives in Management, 14(3), pp. 8-20.

Rugman, A. M. (1981) 'Inside the Multinationals: The Economics of Internal Markets'. New York: Columbia University.

Rugman, A. M. (2005) 'The Regional Multinationals: MNEs and 'Global' Strategic Management'. Cambridge UK: Cambridge University Press.

Rugman, A. M., Oh, C. H. and Lim, D. (2012) 'The regional and global competitiveness of multinational firms', Journal of the Academy of Marketing Science, 40(2), pp. 218-235.

Rugman, A. M. and Verbeke, A. (1992) 'A Note on the Transnational Solution and the Transaction Cost Theory of Multinational Strategic Management', Journal of International Business Studies, 23(4), pp. 761-771.

Rugman, A. M. and Verbeke, A. (2004) 'A perspective on regional and global strategies of multinational enterprises', Journal of International Business Studies, 35(1), pp. 3-18.

Rugman, A. M., Verbeke, A. and Nguyen, Q. T. K. (2011) 'Fifty Years of International Business Theory and Beyond', Management International Review, 51(6), pp. 755-786.

Ruigrok, W., Georgakakis, D. and Greve, P. (2013). 'Regionalization strategy and performance'. Multinational Business Review, 21(1), pp. 6-24.

Salomon, R. and Wu, Z. (2012) 'Institutional distance and local isomorphism strategy', Journal of International Business Studies, 43(4), pp. 343-367.

Sanchez, R. (1995) 'Strategic flexibility in product competition', Strategic Management Journal, 16(S1), pp. 135-159.

Sapienza, H.J., Auttio, E., George, G. and Zahra, S.A. (2006) 'A Capabilities Perspective on the Effects of Early Internationalization on Firm Survival and Growth', Academy of Management Review 31(4), pp. 914-933.

Schotter, A. P., Stallkamp, M. and Pinkham, B. C. (2017). 'MNE headquarters disaggregation: The formation antecedents of regional management centers'. Journal of Management Studies 54(8), 11441169.

Suarez, F.F. and Lanzolla, G. (2007). 'The role of environmental dynamics in building a first mover advantage', Academy of Management Review 32(2), pp. 377-392.

Sukpanich, N. and Rugman, M.A. (2007), 'Intra-regional sales, product diversity, and the 
performance in merchandising multinationals', Journal of International Management, 13(2), pp. 131146.

Tallman, S. and Li, J. (1996) 'Effects of international diversity and product diversity on the performance of multinational firms', Academy of Management Journal, 39(1), pp. 179-196.

Teece, D.J. (1982) 'Towards an economic theory of the multiproduct firm', Journal of Economic Behavior and Organization 3(1), pp. 39-63.

Varadarajan, P. R., and Ramanujam, V. (1990). 'The corporate performance conundrum: A synthesis of contemporary views and extensions'. Journal of Management Studies, 27(5), pp. 463-483.

Verbeke, A. and Asmussen, C. G. (2016) 'Global, Local, or Regional? The Locus of MNE Strategies', Journal of Management Studies, 53(6), pp. 1051-1075.

Verbeke, A., and Kano, L. (2016). 'An internalization theory perspective on the global and regional strategies of multinational enterprises'. Journal of World Business, 51(1), 83-92.

Verbeke, A., Kano, L. and Yuan, W. (2016) 'Inside the regional multinationals: A new value chain perspective on subsidiary capabilities', International Business Review, 25(3), pp. 785-793.

Verbeke, A., van Tulder, R. and Voinea, L. (2012) 'New Policy Challenges for European Multinationals: A Resource Bundling Perspective'. London: Emerald Publishing.

Wiersema, M. F. and Bowen, H. P. (2011) 'The relationship between international diversification and firm performance: Why it remains a puzzle', Global Strategy Journal, 1(1-2), pp. 152-170.

Williamson, O. E. (1985) 'The economic institutions of capitalism: Firms, Markets, Relational Contracting'. New York: The Free Press; London: Collier Macmillan Publishers.

Yang, Y., Martins, P. S. and Driffield, N. (2013) 'Multinational Performance and the Geography of FDI', Management International Review, 53(6), pp. 763-794.

Yeung, H. W. (2009) 'Regional Development and the Competitive Dynamics of Global Production Networks: An East Asian Perspective', Regional Studies, 43(3), pp. 325-351.

Young, S., Hood, N. and Peters, E. (1994) 'Multinational Enterprises and Regional Economic Development', Regional Studies, 28(7), pp. 657-677.

Zaheer, S. and Mosakowski, E. (1997) 'The dynamics of the liability of foreignness: A global study of survival in financial services', Strategic Management Journal, 18(6), pp. 439-463. 
Table 1: Percentage of firms operating in Regions 1 to 4, and categories used to define coverage across these regions

\begin{tabular}{|c|c|c|c|c|c|}
\hline $\begin{array}{c}\text { Region } \\
\text { combination }\end{array}$ & $\begin{array}{l}\% \text { of } \\
\text { firms }\end{array}$ & $\begin{array}{c}\text { Categorical } \\
\text { dummy }\end{array}$ & Region combination & $\%$ of firms & $\begin{array}{c}\text { Categorical } \\
\text { dummy }\end{array}$ \\
\hline Within US only & 36.98 & $\begin{array}{l}\text { Reference } \\
\text { category }\end{array}$ & $\begin{array}{r}\text { US \& Europe \& } \\
\text { Americas }\end{array}$ & 6.40 & $D_{4}$ \\
\hline US \& Europe only & 17.53 & $D_{1}$ & US \& Europe \& Asia & 16.57 & $D_{5}$ \\
\hline $\begin{array}{r}\text { US \& Americas } \\
\text { only }\end{array}$ & 5.92 & $D_{2}$ & $\begin{array}{r}\text { US \& Americas \& } \\
\text { Asia }\end{array}$ & 1.36 & $D_{6}$ \\
\hline US \& Asia only & 3.6 & $D_{3}$ & $\begin{array}{r}\text { US \& Europe \& } \\
\text { Americas \& Asia }\end{array}$ & 11.52 & $D_{7}$ \\
\hline
\end{tabular}


Table 2: Descriptive statistics of independent variables

\begin{tabular}{|c|c|c|c|c|}
\hline & Mean & Std. Dev. & Min & Max \\
\hline $\operatorname{avg} I_{2}$ & 0.065 & 0.102 & 0.000 & 0.794 \\
\hline $\operatorname{avgI}_{3}$ & 0.014 & 0.042 & 0.000 & 0.524 \\
\hline $\operatorname{avgI}_{4}$ & 0.030 & 0.077 & 0.000 & 0.684 \\
\hline $\operatorname{avg} P D$ & 0.392 & 0.203 & 0.130 & 1.000 \\
\hline$\Delta a v g I_{2}$ & 0.019 & 0.036 & -0.200 & 0.250 \\
\hline$\Delta a v g I_{3}$ & 0.004 & 0.014 & -0.075 & 0.165 \\
\hline$\Delta a v g I_{4}$ & 0.010 & 0.030 & -0.065 & 0.247 \\
\hline $\operatorname{avg} I_{1}$ & 0.413 & 0.247 & 0.000 & 1.000 \\
\hline assets & 0.011 & 0.042 & 0.000 & 1.000 \\
\hline employees & 0.024 & 0.067 & 0.000 & 1.000 \\
\hline subsidiaries & 0.018 & 0.055 & 0.000 & 1.000 \\
\hline$D_{1}$ & 0.175 & 0.380 & 0 & 1 \\
\hline$D_{2}$ & 0.059 & 0.236 & 0 & 1 \\
\hline$D_{3}$ & 0.036 & 0.188 & 0 & 1 \\
\hline$D_{4}$ & 0.064 & 0.244 & 0 & 1 \\
\hline$D_{5}$ & 0.165 & 0.371 & 0 & 1 \\
\hline$D_{6}$ & 0.013 & 0.115 & 0 & 1 \\
\hline$D_{7}$ & 0.115 & 0.319 & 0 & 1 \\
\hline
\end{tabular}


Table 3: Pearson correlation coefficients of continuous independent variables

\begin{tabular}{|c|c|c|c|c|c|c|c|c|c|c|}
\hline & $\operatorname{avgI_{2}}$ & $\operatorname{avgI_{3}}$ & $\operatorname{avgI}_{4}$ & $\operatorname{avgPD}$ & $\Delta a v g I_{2}$ & $\Delta a v g I_{3}$ & $\Delta a v g I_{4}$ & $\operatorname{avg} I_{1}$ & avgAssets & employees \\
\hline $\operatorname{avg} I_{2}$ & 1 & & & & & & & & & \\
\hline $\operatorname{avgI}_{3}$ & 0.01 & 1 & & & & & & & & \\
\hline $\operatorname{avg} I_{4}$ & 0.10 & 0.02 & 1 & & & & & & & \\
\hline $\operatorname{avg} P D$ & 0.03 & 0.03 & -0.01 & 1 & & & & & & \\
\hline$\Delta a v g I_{2}$ & 0.70 & 0.04 & 0.05 & 0.00 & 1 & & & & & \\
\hline$\Delta a v g I_{3}$ & -0.02 & 0.79 & 0.00 & 0.03 & 0.01 & 1 & & & & \\
\hline$\Delta a v g I_{4}$ & 0.04 & -0.02 & 0.90 & -0.07 & 0.10 & 0.01 & 1 & & & \\
\hline $\operatorname{avg} I_{1}$ & -0.06 & 0.21 & -0.14 & 0.12 & -0.12 & 0.01 & -0.18 & 1 & & \\
\hline assets & 0.03 & 0.03 & -0.01 & 0.14 & -0.07 & -0.04 & -0.06 & 0.07 & 1 & \\
\hline employees & 0.05 & 0.09 & 0.01 & 0.16 & -0.06 & -0.03 & -0.07 & 0.12 & 0.66 & 1 \\
\hline subsidiaries & 0.04 & 0.01 & 0.03 & 0.20 & -0.04 & 0.00 & -0.06 & 0.07 & 0.28 & 0.48 \\
\hline
\end{tabular}


Table 4: GDP and per capita GDP growth rates across decades and supra-national regions.

\begin{tabular}{|l|r|r|r|r|r|r|}
\hline & $\mathbf{1 9 6 1 - 7 0}$ & $\mathbf{1 9 7 1 - 8 0}$ & $\mathbf{1 9 8 1 - 9 0}$ & $\mathbf{1 9 9 1 - 2 0 0 0}$ & $\mathbf{2 0 0 1 - 1 0}$ & $\mathbf{1 9 6 1 - 2 0 1 0}$ \\
\hline GDP growth & & & & & & \\
\hline Asia Pacific & 7.9 & 4.9 & 5.1 & 4.8 & 6.1 & 5.7 \\
\hline Americas & 4.7 & 4.2 & 2.7 & 3.3 & 2.1 & 3.3 \\
\hline Europe & 5.3 & 3.2 & 2.5 & 1.0 & 2.2 & 2.7 \\
\hline Africa & 4.1 & 4.2 & 2.4 & 2.7 & 5.5 & 3.8 \\
\hline $\begin{array}{l}\text { GDP per } \\
\text { capita growth }\end{array}$ & & & & & & \\
\hline Asia Pacific & 5.5 & 2.7 & 3.0 & 3.3 & 4.9 & 3.9 \\
\hline Americas & 2.7 & 2.3 & 1.0 & 1.8 & 0.9 & 1.7 \\
\hline Europe & 4.4 & 2.5 & 2.0 & 0.8 & 1.9 & 2.2 \\
\hline Africa & 1.6 & 1.5 & -0.5 & 0.1 & 2.9 & 1.1 \\
\hline
\end{tabular}

Source: IMF World Economic Outlook and World Bank. 
Table 5: OLS Coefficients (and robust standard errors) from Model 1 using lagged "between" estimator

\begin{tabular}{|c|c|c|c|c|}
\hline & Model 1a & Model 1b & Model 1c & Model 1d \\
\hline \multicolumn{5}{|l|}{ Covariates } \\
\hline (Intercept) & $\begin{array}{l}-53.932 * * * \\
(11.246)\end{array}$ & $\begin{array}{l}-68.459 * * * \\
(13.146)\end{array}$ & $\begin{array}{l}-55.637 * * * \\
(11.590)\end{array}$ & $\begin{array}{l}-52.365 * * * \\
(11.485)\end{array}$ \\
\hline $\operatorname{avg} I_{2}$ (lagged) & $\begin{array}{l}-49.422 \\
(69.350)\end{array}$ & $\begin{array}{l}124.75 * * \\
(52.250) \\
\end{array}$ & $\begin{array}{l}-50.217 \\
(69.377) \\
\end{array}$ & $\begin{array}{l}-51.156 \\
(69.736) \\
\end{array}$ \\
\hline $\operatorname{avg} I_{3}$ (lagged) & $\begin{array}{l}43.596 \\
(37.973) \\
\end{array}$ & $\begin{array}{l}34.424 \\
(42.871) \\
\end{array}$ & $\begin{array}{l}206.21 * * \\
(85.356) \\
\end{array}$ & $\begin{array}{l}40.842 \\
(38.719) \\
\end{array}$ \\
\hline $\operatorname{avg} I_{4}$ (lagged) & $\begin{array}{l}96.399 * * * \\
(32.470)\end{array}$ & $\begin{array}{l}106.13 * * * \\
(34.301)\end{array}$ & $\begin{array}{l}98.217 \text { *** } \\
(3.255)\end{array}$ & $\begin{array}{l}54.922 \\
(47.449) \\
\end{array}$ \\
\hline \multicolumn{5}{|l|}{ Interactions } \\
\hline $\operatorname{avgI} I_{2} * \operatorname{avgPD}$ & & $\begin{array}{l}-477.94 * * \\
(199.68) \\
\end{array}$ & & \\
\hline $\operatorname{avg} I_{3} * \operatorname{avg} P D$ & & & $\begin{array}{l}-374.40 * * \\
(167.47) \\
\end{array}$ & \\
\hline $\operatorname{avgI} I_{4} * \operatorname{avgPD}$ & & & & $\begin{array}{l}130.63 \\
(126.32) \\
\end{array}$ \\
\hline \multicolumn{5}{|l|}{ Controls } \\
\hline $\operatorname{avg} I_{1}$ (lagged) & $\begin{array}{l}52.815 * * * \\
(13.928) \\
\end{array}$ & $\begin{array}{l}53.674 * * * \\
(13.950) \\
\end{array}$ & $\begin{array}{l}52.477 * * * \\
(13.888) \\
\end{array}$ & $\begin{array}{l}52.762 * * * \\
(13.922) \\
\end{array}$ \\
\hline $\operatorname{avgPD}$ (lagged) & $\begin{array}{l}30.623 * * \\
(13.953)\end{array}$ & $\begin{array}{l}67.621 * * * \\
(17.100)\end{array}$ & $\begin{array}{l}35.062 * * \\
(1.498)\end{array}$ & $\begin{array}{l}26.596 * \\
(15.383) \\
\end{array}$ \\
\hline assets & $\begin{array}{l}0.000 \\
(0.000)\end{array}$ & $\begin{array}{l}0.000 \\
(0.000)\end{array}$ & $\begin{array}{l}0.000 \\
(0.000)\end{array}$ & $\begin{array}{l}0.000 \\
(0.000)\end{array}$ \\
\hline subsidiaries & $\begin{array}{l}64.049 * \\
(37.063)\end{array}$ & $\begin{array}{l}72.119 * * \\
(35.661)\end{array}$ & $\begin{array}{l}61.058 * \\
(37.213)\end{array}$ & $\begin{array}{l}65.250 * \\
(37.068)\end{array}$ \\
\hline employees & $\begin{array}{l}67.734 * \\
(35.065) \\
\end{array}$ & $\begin{array}{l}76.395 * * \\
(36.516) \\
\end{array}$ & $\begin{array}{l}78.057 * * \\
(37.605) \\
\end{array}$ & $\begin{array}{l}64.748 * \\
(34.583) \\
\end{array}$ \\
\hline$D_{1}$ & $\begin{array}{l}1.637 \\
(8.790) \\
\end{array}$ & $\begin{array}{l}1.876 \\
(8.547) \\
\end{array}$ & $\begin{array}{l}1.5723 \\
(8.804) \\
\end{array}$ & $\begin{array}{l}2.046 \\
(8.815) \\
\end{array}$ \\
\hline$D_{2}$ & $\begin{array}{l}4.599 \\
(5.421) \\
\end{array}$ & $\begin{array}{l}4.122 \\
(5.736) \\
\end{array}$ & $\begin{array}{l}4.637 \\
(5.329) \\
\end{array}$ & $\begin{array}{l}4.877 \\
(5.371) \\
\end{array}$ \\
\hline$D_{3}$ & $\begin{array}{l}-12.429 \\
(13.706)\end{array}$ & $\begin{array}{l}-13.282 \\
(13.558)\end{array}$ & $\begin{array}{l}-12.611 \\
(13.672)\end{array}$ & $\begin{array}{l}-12.694 \\
(13.796)\end{array}$ \\
\hline$D_{4}$ & $\begin{array}{l}12.741 * \\
(6.858)\end{array}$ & $\begin{array}{l}12.482 * \\
(6.915)\end{array}$ & $\begin{array}{l}11.492 * \\
(6.722)\end{array}$ & $\begin{array}{l}13.312^{*} \\
(6.878) \\
\end{array}$ \\
\hline$D_{5}$ & $\begin{array}{l}-9.169 \\
(14.816) \\
\end{array}$ & $\begin{array}{l}-7.691 \\
(14.551) \\
\end{array}$ & $\begin{array}{l}-9.418 \\
(14.833) \\
\end{array}$ & $\begin{array}{l}-9.764 \\
(14.954) \\
\end{array}$ \\
\hline$D_{6}$ & $\begin{array}{l}-3.646 \\
(11.653) \\
\end{array}$ & $\begin{array}{l}-0.996 \\
(12.019) \\
\end{array}$ & $\begin{array}{l}-3.472 \\
(11.573) \\
\end{array}$ & $\begin{array}{l}-2.907 \\
(11.747) \\
\end{array}$ \\
\hline$D_{7}$ & $\begin{array}{l}-1.188 \\
(11.869) \\
\end{array}$ & $\begin{array}{l}0.186 \\
(11.911) \\
\end{array}$ & $\begin{array}{l}-1.611 \\
(11.859) \\
\end{array}$ & $\begin{array}{l}-1.584 \\
(11.877) \\
\end{array}$ \\
\hline Goodness of fit & $\begin{array}{l}\mathrm{N}=960 \\
\text { Adj. } \mathrm{R} \text {-squared: } \\
0.04519 \\
\text { F-statistic: } 4.026 \text { on } \\
15 \text { and } 944 \mathrm{DF}, \mathrm{p}- \\
\text { value: } 0.000\end{array}$ & $\begin{array}{l}\mathrm{N}=960 \\
\text { Adj. R-squared: } \\
0.06336 \\
\text { F-statistic: } 5.054 \text { on } \\
16 \text { and } 943 \mathrm{DF}, \mathrm{p}- \\
\text { value: } 0.000\end{array}$ & $\begin{array}{l}\mathrm{N}=960 \\
\text { Adj. R-squared: } \\
0.04557 \\
\text { F-statistic: } 3.862 \text { on } \\
16 \text { and } 943 \mathrm{DF}, \mathrm{p}- \\
\text { value: } 0.000\end{array}$ & $\begin{array}{l}\mathrm{N}=960 \\
\text { Adj. R-squared: } \\
0.04473 \\
\text { F-statistic: } 3.807 \text { on } \\
16 \text { and } 943 \mathrm{DF}, \mathrm{p}- \\
\text { value: } 0.000\end{array}$ \\
\hline
\end{tabular}

$* * * \mathrm{p}<0.01 ; * * \mathrm{p}<0.05 ; * \mathrm{p}<0.1$ 
Table 6: OLS Coefficients (and robust standard errors) from Model 2 using lagged "between" specification

\begin{tabular}{|c|c|c|c|c|}
\hline & Model 2a & Model 2b & Model 2c & Model 2d \\
\hline \multicolumn{5}{|l|}{ Covariates } \\
\hline (Intercept) & $\begin{array}{l}-54.576 * * * \\
(11.470) \\
\end{array}$ & $\begin{array}{l}-51.139 * * * \\
(14.643) \\
\end{array}$ & $\begin{array}{l}-54.980 * * * \\
(11.761) \\
\end{array}$ & $\begin{array}{l}-53.71 * * * \\
(8.132) \\
\end{array}$ \\
\hline$\Delta a v g I_{2}$ (lagged) & $\begin{array}{l}-176.57 \\
(182.97) \\
\end{array}$ & $\begin{array}{l}252.93 * \\
(150.69) \\
\end{array}$ & $\begin{array}{l}-176.95 \\
(182.94) \\
\end{array}$ & $\begin{array}{l}-179.42 * * \\
(81.62)\end{array}$ \\
\hline$\Delta a v g I_{3}$ (lagged) & $\begin{array}{l}167.04 \\
(117.56)\end{array}$ & $\begin{array}{l}128.96 \\
(120.16) \\
\end{array}$ & $\begin{array}{l}292.21 \\
(299.74)\end{array}$ & $\begin{array}{l}167.8 \\
(207.0)\end{array}$ \\
\hline$\Delta a v g I_{4}$ (lagged) & $\begin{array}{l}275.18 * * * \\
(92.776)\end{array}$ & $\begin{array}{l}259.85 * * \\
(106.97)\end{array}$ & $\begin{array}{l}274.78 * * * \\
(92.775)\end{array}$ & $\begin{array}{l}201.7 \\
(169.5)\end{array}$ \\
\hline \multicolumn{5}{|l|}{ Interactions } \\
\hline$\Delta a v g I_{2} * \operatorname{avg} P D$ & & $\begin{array}{l}-1259.6 * * \\
(625.17) \\
\end{array}$ & & \\
\hline$\Delta a v g I_{3} * \operatorname{avg} P D$ & & & $\begin{array}{l}-305.20 \\
(568.41)\end{array}$ & \\
\hline$\Delta a v g I_{4} * \operatorname{avg} P D$ & & & & $\begin{array}{l}249.87 \\
(440.9) \\
\end{array}$ \\
\hline \multicolumn{5}{|l|}{ Controls } \\
\hline $\operatorname{avg} I_{1}$ (lagged) & $\begin{array}{l}52.784 * * * \\
(13.723) \\
\end{array}$ & $\begin{array}{l}43.349 * * * \\
(14.308) \\
\end{array}$ & $\begin{array}{l}52.760 * * * \\
(13.719) \\
\end{array}$ & $\begin{array}{l}52.95 * * * \\
(11.89) \\
\end{array}$ \\
\hline $\operatorname{avg} P D$ (lagged) & $\begin{array}{l}32.494 * * * \\
(13.894)\end{array}$ & $\begin{array}{l}49.606 * * * \\
(18.241) \\
\end{array}$ & $\begin{array}{l}33.618 * * \\
(15.005)\end{array}$ & $\begin{array}{l}29.92 * * \\
(13.60)\end{array}$ \\
\hline assets & $\begin{array}{l}0.000 \\
(0.000)\end{array}$ & $\begin{array}{l}0.000 \\
(0.000)\end{array}$ & $\begin{array}{l}0.000 \\
(0.000)\end{array}$ & $\begin{array}{l}0.000 \\
(0.000)\end{array}$ \\
\hline subsidiaries & $\begin{array}{l}55.994 \\
(38.864) \\
\end{array}$ & $\begin{array}{l}42.858 \\
(36.965)\end{array}$ & $\begin{array}{l}56.168 \\
(39.021)\end{array}$ & $\begin{array}{l}56.76 \\
(48.60)\end{array}$ \\
\hline employees & $\begin{array}{l}75.617 * \\
(36.188)\end{array}$ & $\begin{array}{l}66.206 * \\
(31.869)\end{array}$ & $\begin{array}{l}75.181 * * \\
(36.065)\end{array}$ & $\begin{array}{l}75.96 * \\
(47.92)\end{array}$ \\
\hline$D_{1}$ & $\begin{array}{l}2.099 \\
(7.131) \\
\end{array}$ & $\begin{array}{l}2.635 \\
(7.563) \\
\end{array}$ & $\begin{array}{l}2.088 \\
(7.133) \\
\end{array}$ & $\begin{array}{l}2.295 \\
(8.174) \\
\end{array}$ \\
\hline$D_{2}$ & $\begin{array}{l}3.335 \\
(5.490)\end{array}$ & $\begin{array}{l}0.106 \\
(5.275)\end{array}$ & $\begin{array}{l}3.558 \\
(5.479)\end{array}$ & $\begin{array}{l}3.360 \\
(12.57)\end{array}$ \\
\hline$D_{3}$ & $\begin{array}{l}-14.613 \\
(13.746) \\
\end{array}$ & $\begin{array}{l}-9.963 \\
(10.399) \\
\end{array}$ & $\begin{array}{l}-14.584 \\
(13.740) \\
\end{array}$ & $\begin{array}{l}-14.72 \\
(14.98) \\
\end{array}$ \\
\hline$D_{4}$ & $\begin{array}{l}11.946 * * \\
(5.8211)\end{array}$ & $\begin{array}{l}10.864 \\
(6.029)\end{array}$ & $\begin{array}{l}11.979 * * \\
(5.813)\end{array}$ & $\begin{array}{l}12.11 \\
(11.65)\end{array}$ \\
\hline$D_{5}$ & $\begin{array}{l}-8.754 \\
(14.315)\end{array}$ & $\begin{array}{l}-10.476 \\
(15.074)\end{array}$ & $\begin{array}{l}-8.761 \\
(14.317)\end{array}$ & $\begin{array}{l}-9.211 \\
(8.964)\end{array}$ \\
\hline$D_{6}$ & $\begin{array}{l}-1.685 \\
(11.314)\end{array}$ & $\begin{array}{l}-1.650 \\
(11.790)\end{array}$ & $\begin{array}{l}-1.985 \\
(11.654)\end{array}$ & $\begin{array}{l}-0.891 \\
(21.08)\end{array}$ \\
\hline$D_{7}$ & $\begin{array}{l}-1.334 \\
(9.805)\end{array}$ & $\begin{array}{l}-4.344 \\
(9.882)\end{array}$ & $\begin{array}{l}-1.376 \\
(9.817)\end{array}$ & $\begin{array}{l}-1.608 \\
(9.375)\end{array}$ \\
\hline Goodness of Fit & $\begin{array}{l}\mathrm{N}=960 \\
\text { Adj. } \mathrm{R} \text {-squared: } \\
0.04917 \\
\text { F-statistic: } 4.306 \text { on } \\
16 \text { and } 943 \mathrm{DF}, \mathrm{p}- \\
\text { value: } 0.000\end{array}$ & $\begin{array}{l}\mathrm{N}=960 \\
\text { Adj. } \mathrm{R} \text {-squared: } \\
0.05386 \\
\text { F-statistic: } 3.977 \text { on } \\
16 \text { and } 943 \mathrm{DF}, \mathrm{p}- \\
\text { value: } 0.000\end{array}$ & $\begin{array}{l}\mathrm{N}=960 \\
\text { Adj. } \mathrm{R} \text {-squared: } \\
0.04825 \\
\text { F-statistic: } 4.039 \text { on } \\
16 \text { and } 943 \mathrm{DF}, \mathrm{p}- \\
\text { value: } 0.000\end{array}$ & $\begin{array}{l}\mathrm{N}=960 \\
\text { Adj. R-squared: } \\
0.04848 \\
\text { F-statistic: } 4.054 \text { on } \\
16 \text { and } 943 \mathrm{DF}, \mathrm{p}- \\
\text { value: } 0.000\end{array}$ \\
\hline
\end{tabular}

$* * * \mathrm{p}<0.01 ; * * \mathrm{p}<0.05 ; * \mathrm{p}<0.1$ 
Table 7: Panel estimates for Equations 1 and 2 using Fixed and Random Effects respectively

\begin{tabular}{|c|c|c|c|}
\hline \multicolumn{2}{|c|}{$\begin{array}{c}\text { Equation } 1 \text { (Degree) } \\
\text { Random Effects }\end{array}$} & \multicolumn{2}{|c|}{$\begin{array}{c}\text { Equation } 2 \text { (Speed) } \\
\text { Fixed Effects } \\
\end{array}$} \\
\hline \multicolumn{2}{|l|}{ Covariates } & \multicolumn{2}{|l|}{ Covariates } \\
\hline Intercept & $\begin{array}{l}-12.524 * * * \\
(0.086) \\
\end{array}$ & & \\
\hline$I_{2}$ (lagged) & $\begin{array}{l}-10.331 * * * \\
(0.137) \\
\end{array}$ & $\Delta I_{2}$ (lagged) & $\begin{array}{l}-21.355^{* * *} \\
(7.644)\end{array}$ \\
\hline$I_{3}$ (lagged) & $\begin{array}{l}-9.630 * * * \\
(0.274) \\
\end{array}$ & $\Delta I_{3}$ (lagged) & $\begin{array}{l}9.627 \\
(14.568) \\
\end{array}$ \\
\hline$I_{4}$ (lagged) & $\begin{array}{l}5.700 * * * \\
(0.165) \\
\end{array}$ & $\Delta I_{4}$ (lagged) & $\begin{array}{l}6.097 \\
(11.287) \\
\end{array}$ \\
\hline Controls $^{1}$ & & Controls $^{2}$ & \\
\hline$I_{1}$ (lagged) & $\begin{array}{l}0.746 * * * \\
(0.055) \\
\end{array}$ & $I_{1}$ (lagged) & $\begin{array}{l}-2.593 \\
(2.782)\end{array}$ \\
\hline$P D$ (lagged) & $\begin{array}{l}-9.117 * * * \\
(0.087) \\
\end{array}$ & $P D$ (lagged) & $\begin{array}{l}-2.283 \\
(4.628)\end{array}$ \\
\hline assets & $\begin{array}{l}-3.933 * * * \\
(1.123)\end{array}$ & & \\
\hline subsidiaries & $\begin{array}{l}80.560 * * * \\
(0.692)\end{array}$ & & \\
\hline employees & $\begin{array}{l}83.703 * * * \\
(83.703)\end{array}$ & & \\
\hline Firm level dummies & No & Firm level dummies & Yes \\
\hline Diagnostics & & Diagnostics & \\
\hline No. of Firms & 715 & No. of Firms & 730 \\
\hline \multicolumn{4}{|l|}{ Variance (share) } \\
\hline Idiosyncratic & $\begin{array}{l}2345.831 \\
(0.42) \\
\end{array}$ & & \\
\hline Individual & $\begin{array}{l}3135.124 \\
(0.57)\end{array}$ & & \\
\hline Time & $\begin{array}{l}22.765 \\
(0.01) \\
\end{array}$ & & \\
\hline Chi-square & $43.643 * * *$ & F statistic & $1.868^{*}$ \\
\hline Hausman-Wu p-value ${ }^{3}$ & 0.447 & Hausman-Wu p-value $^{3}$ & $0.001 * * *$ \\
\hline
\end{tabular}

${ }^{1} D_{j}$ s, the regional coverage dummies, are not included in the model. Once included, the number of coefficients to be estimated (16) becomes higher than the number of time periods available (10), and the corresponding model is unidentifiable.

2 Time invariant control variables, such as assets, subsidiaries, employees and regional coverage dummies cannot be included in the Fixed effects estimation.

${ }^{3}$ A non-significant Hausman-Wu test implies that both Random and Fixed effects are consistent, so the Random model should be chosen as it is more efficient. A significant test on the other hand implies that the Random model is inconsistent while Fixed effects is consistent, implying that the latter should be chosen. 
Table 8: Overall results in terms of the hypotheses tested.

\begin{tabular}{|l|l|l|}
\hline Hypothesis & Supported? & Clarifications \\
\hline $\begin{array}{l}\text { H1: The underlying economic growth } \\
\text { of a region positively moderates the } \\
\text { linkage between the degree of } \\
\text { operations and firm performance, } \\
\text { that is, the incremental impact of the } \\
\text { degree of operations within specific } \\
\text { regions on firm performance will be } \\
\text { greater in regions experiencing high } \\
\text { growth rates. }\end{array}$ & Yes & $\begin{array}{l}\text { Largest effect of the degree of operations is for } \\
\text { operations within Asia-Pacific, which is also the } \\
\text { fastest growing region. No significant impact within } \\
\text { the Americas and Europe (except under specific } \\
\text { conditions related to product diversification). }\end{array}$ \\
\hline $\begin{array}{l}\text { H2: The underlying economic growth } \\
\text { of a region positively moderates the } \\
\text { linkage between the speed of } \\
\text { operations and firm performance, } \\
\text { that is, the incremental impact of the } \\
\text { speed of operations within specific } \\
\text { regions on firm performance will be } \\
\text { greater in regions experiencing high } \\
\text { growth rates. }\end{array}$ & Yes & $\begin{array}{l}\text { Positive marginal effect of the speed of expansion on } \\
\text { performance within Asia-Pacific region. No } \\
\text { significant impact within the Americas and Europe } \\
\text { (except under specific conditions related to product } \\
\text { diversification, only for Europe). }\end{array}$ \\
\hline $\begin{array}{l}\text { H3: Product diversity negatively } \\
\text { moderates the linkages between the } \\
\text { degree and speed of operations and } \\
\text { firm performance, in the sense that, } \\
\text { incremental benefits from degree and } \\
\text { speed of operations will be less for } \\
\text { firms with greater product diversity. }\end{array}$ & Partial & $\begin{array}{l}\text { Supported only for the relatively slower growing } \\
\text { regions. For Region 3, product diversity negatively } \\
\text { moderates the degree of regional operations and } \\
\text { performance link as well as the speed and } \\
\text { performance link. For Region 2, the moderation is } \\
\text { only seen in the degree of regional operations and } \\
\text { performance linkage. For Region 4, the fastest } \\
\text { growing region, no such moderation effect is } \\
\text { observed. }\end{array}$ \\
\hline
\end{tabular}


Figure 1: Influence of product diversity on the relationship between degree of Region 2 operations and performance

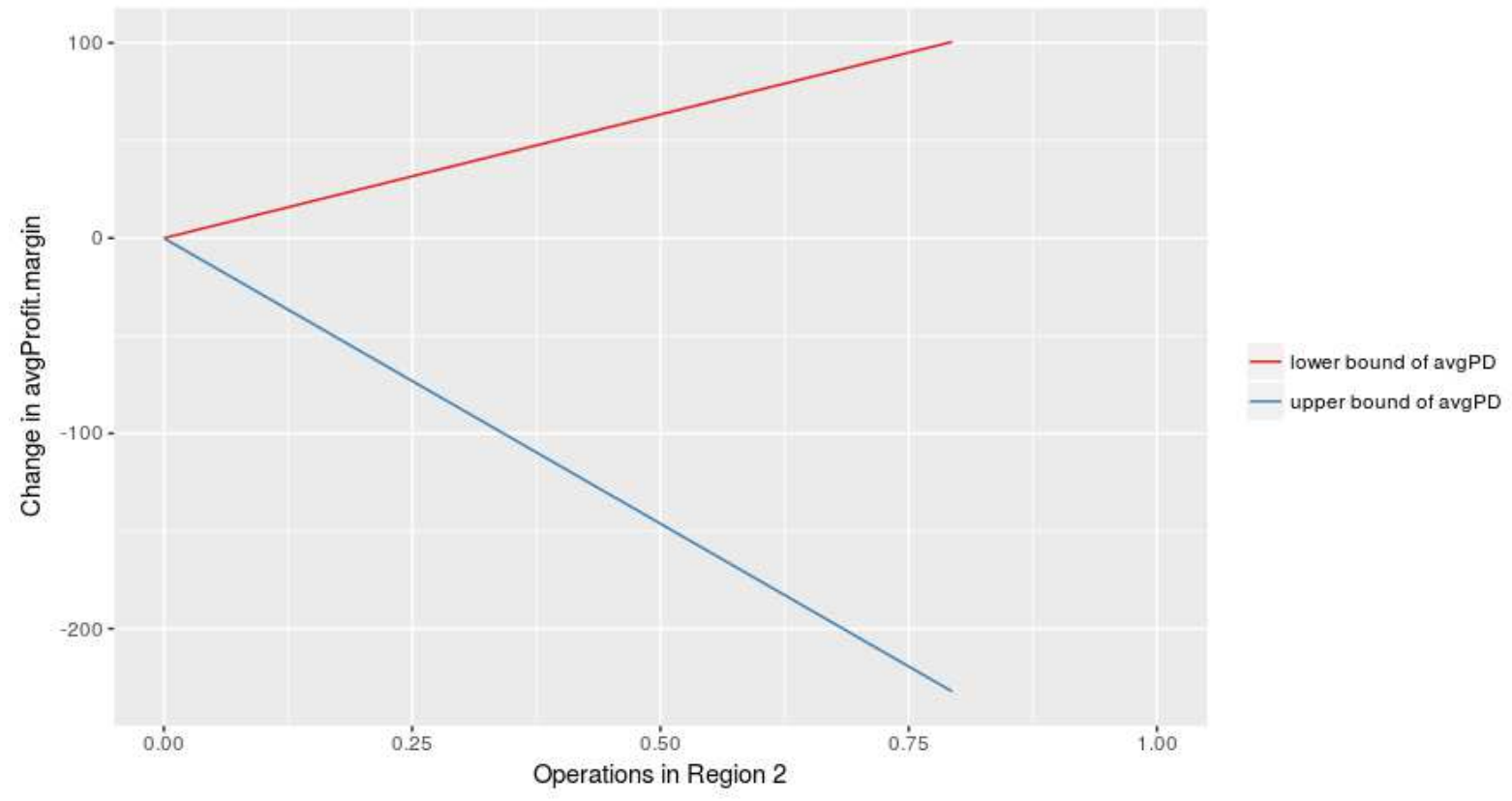

Figure 2: Influence of product diversification on the relationship between degree of Region 3 operations and performance

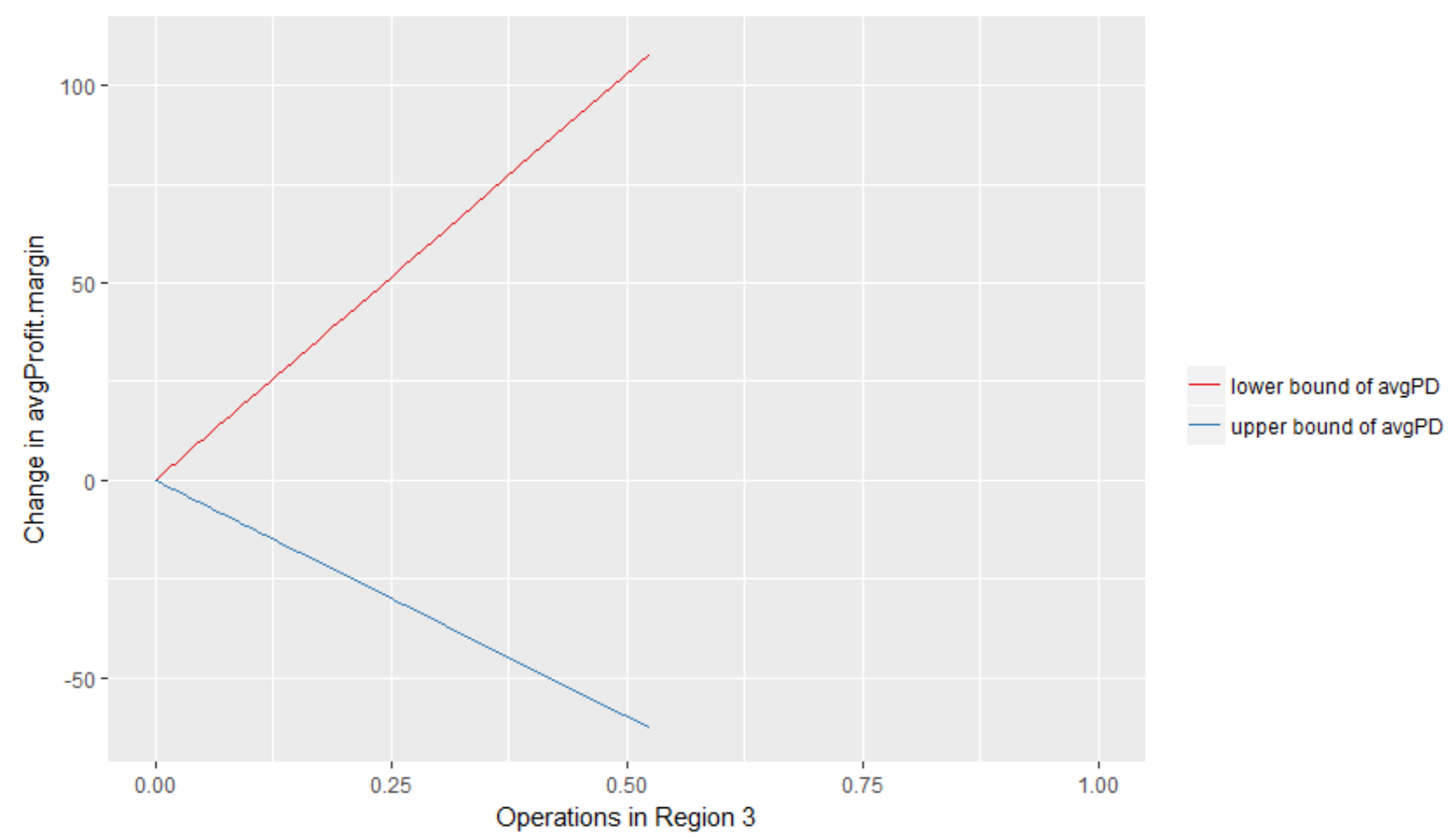


Figure 3: Influence of product diversification on the relationship between speed of Region 2 operations and performance (in Region 2)

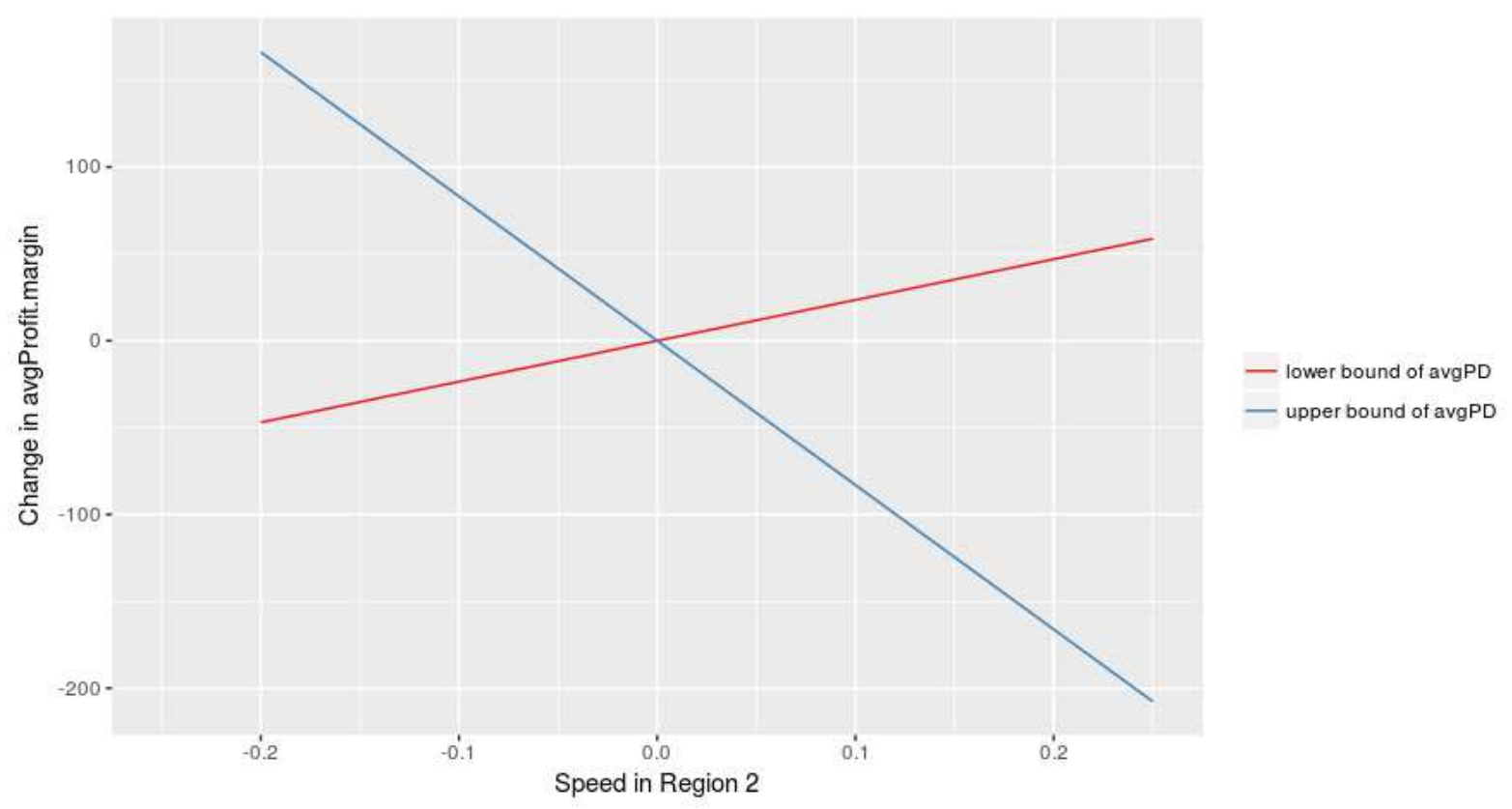

